Egyptian Journal of Aquatic Biology \& Fisheries

Zoology Department, Faculty of Science,

Ain Shams University, Cairo, Egypt.

ISSN 1110 - 6131 Vol. 22(3): 159- 182 (2018)

ejabf.journals.ekb.eg

\title{
Biochemical and histological assessment of some heavy metals on Biomphalaria alexandrina snails and Oreochromis niloticus fish in Lake Burullus, Egypt.
}

\author{
Hanaa M. M. El-Khayat ${ }^{1}$,Sohair Abd-Elkawy ${ }^{2}$, Nouran A. Abou- Ouf ${ }^{2}$, \\ Mervat A. Ahmed ${ }^{2}$ and Wafaa A. Mohammed ${ }^{1}$ * \\ 1- Depart. of Env. Research and Medical Malacology, Theodor Bilharz Research \\ Institute, Egypt. \\ 2- Depart. of Zoology, Faculty of Science, Al-Azhar Universty, Cairo, Egypt. \\ * Corresponding author email: freehanaa@ yahoo.com
}

\section{ARTICLE INFO \\ Article History: \\ Received:June 15, 2018 \\ Accepted: July 23, 2018 \\ Available online: July 30, 2018}

Keywords:

Lake Burullus

Heavy metals

Biomphalaria alexandrina

Oreochromis niloticus

Biochemistry

Histology

\begin{abstract}
The quality of water in Lake Burullus was investigated to evaluate its effect on certain biochemical and histological aspects on Biomphalaria alexandrina snail and Oreochromis niloticus fish. The examined lake water quality criteria showed high levels of total dissolved solids (TDS), conductivity (EC), and levels of $\mathrm{Pb}$ and $\mathrm{Fe}$. Sites that adjacent to point of discharging of waste waters showed higher levels of heavy metals and the least levels in dissolved oxygen (DO). The results showed that most of the examined biochemical parameters indicated affected liver (high levels in AST, ALP \& TP and alteration in glucose \& urea levels). Samples of Bahr Tera site in El-Hamoul center and Shakhloba site in Sidi-Salem were the most affected, while samples of Prempal site in Mottobus center were the least. Snails' histopathological examination showed degeneration, edema, hyper trophy and vaculation in head-foot muscles, degeneration and necrotic changes in the digestive gland, irregular shape in mature ova and reduction in sperm number in hermaphrodite gland. As well, fish histopathological investigation illustrated by necrotic change in most examined organs, the common features were: fiber splitting in muscles, cognation of blood vessels of gill filaments, vacuolar degeneration in liver and atrophy in glomeruli and epithelial cells of renal tubules in kidney. It was concluded that Lake Burullus water quality in wastewater discharge areas, adversely affects $B$. alexandrina snails and $O$. niloticus fish, and both can be used as bio-indicators for the presence of pollutants in their habitats.
\end{abstract}

\section{INTRODUCTION}

Lake Burullus is the central of five principal coastal lagoons of northern Egypt. It is a part of Kafr El-Sheikh governorate in the northern part of the delta that lies between the two branches of the Nile. The pollution of aquatic environment with heavy metal has been a worldwide problem during the recent years because they are indestructible and most of them have a toxic effect on organisms (Mac Farlane and Burchette, 2000). Among environmental pollutants, metals are of particular concern due to their toxic effect and ability to bioaccumulation in aquatic ecosystems (Censi, et al., 2006). 
Metals tend to accumulate in water and move up through the food chain; therefore, studies to quantify the level of heavy metals in environment and determine potentially hazardous levels for human are necessary (Haram, 2015). Pollution of the aquatic environment by heavy metals is a major threat to human health and to aquatic organisms (Hamed et al., 2015). They enter to the aquatic systems from different anthropogenic and natural sources, including industrial or domestic wastewater, application of pesticides and fertilizers, leaching from landfills, shipping and harbor activities and atmospheric deposits and geological weathering of the earth crust (Elagba et al ., 2014). Some heavy metals such as iron (Fe), copper $(\mathrm{Cu})$ and zinc (Zn) are essential micronutrients for aquatic fauna and flora, but they may be dangerous at high levels (Zerabruk et al., 2016). Whereas cadmium (Cd) and lead $(\mathrm{Pb})$ are non-essential metals, they are toxic even in trace amounts (Ozturk et al., 2009). Many studies proved that the polluted water caused a severe damage to the cells and different tissues of the fish inhabiting these places (Mohamed, 2009).

Several histological alterations have been reported in the muscle, gills, liver and kidney of fish in response to industrial, sewage and agricultural pollutants. Histopathological alterations can be used as indicators for the effects of various anthropogenic pollutants on organisms and are a reflection of the overall health of the entire population in the ecosystem. Previous studies reported that the exposure of fish to pollutants (agricultural, industrial and sewage) resulted in several pathological alterations in different tissues of fish (Abbas and Ali, 2007). It is believed that the gills of fish exposed to irritants are of the most important organs that are highly affected (Saad et al., 2011). Histological changes have been reported in the liver of fish as a result of exposure to industrial and municipal sewage waste (Syasina et al., 2000), heavy metals (Osman et al., 2009). Histological abnormalities were seen in the muscle of fish as a result of exposure to different toxicants (Abbas and Ali, 2007 and Oliveira Ribeiro et al., 2008). Several pathological lesions were observed in the kidney of $O$. niloticus exposed to ammonia, $\mathrm{Cu}$ and $\mathrm{Pb}$ (Benli et al., 2008; Osman et $a l ., 2009)$. Fish sample can be considered as the most significant indicators in fresh water system for estimation of metals pollution level (Ozturk et al., 2009). As well for snails, several investigators (Ibrahim, 2006; Moolman et al., 2007 and El-Khayat et al., 2015) showed that snails are able to accumulate large quantities of metals in their tissues. This intoxication of the snail is a result not only of soil ingestion but, also of epithelial absorption of the contaminants (Blackmore, 2000). Because the enzymatic activities are regarded as reliable indices of individual responses to environmental stress, they can be used to estimate pollution at population and ecosystem levels (Laszczyca et al., 2004). The use of physiological and biochemical parameters in addition to histopathological changes have been widely used as biomarkers in the health evaluation of animal organisms (El-Khayat et al., 2015).

The present study aims to assess the impact of water quality of Lake Burullus expressed by physic-chemical parameters and some heavy metals on Biomphalaria alexandrina and Oreochromis niloticus collected from Lake Burullus investigating liver and kidney functions and incidence of histological alterations in snail tissues and fish organs; the gills, liver, muscles and kidney.

\section{MATERIALS AND METHODS}

\section{Study area:}

This study was done during the years 2014 and 2015 at seven sites in Lake Burullus that is one of the Nile Delta lakes located between the two main Delta 
promontories; Rosetta and Damietta. It extends between $30^{\circ} 22^{\prime}-31^{\circ} 35^{\prime} \mathrm{N}$ and $30^{\circ}$ $33^{\prime}-31^{\circ} 08^{\prime}$ E. Huge amounts of drainage water (about 4.03 milliar $\mathrm{m}^{3} /$ year) enter the lake from several drains lake: 1) El-Boughaz site: Near El- Boughaz inlet at lakeMediterranean Sea connection, 2) El-Emad site: is located in the northern area of the lake, 3) El-Khashaa site: is located in the eastern area of the lake which receives the drainage water from Khashaa (El-Gharbia) main drain, 4) Bahr-Tera site: is located in the eastern area of the lake which receives the drainage water from No. 7 drain, 5) El-Shakhloba site: is located in the front of Drain No. 9 and receives drainage water from drains Nos. 8 and 9, and 6) El-Hoxa site: It is located in the western area of the lake and receives drainage water from drain No. 11and freshwater from Prembal Canal and 7) Prembal site: is located in the western area of the lake and receives fresh water from The River Nile.

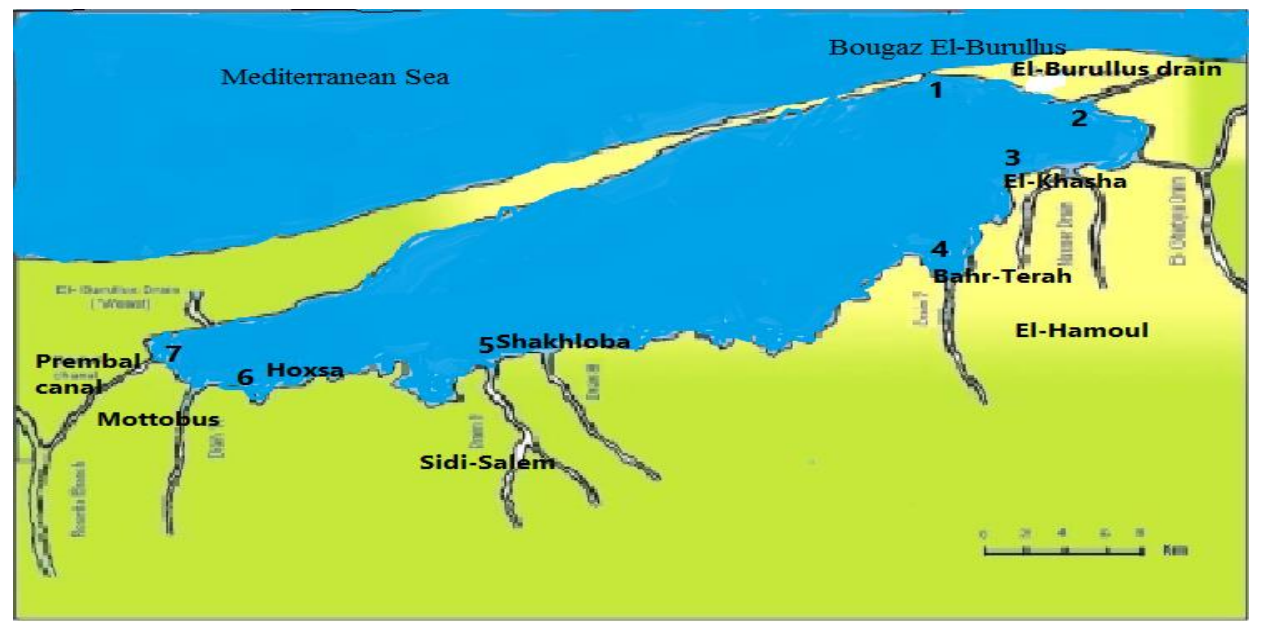

Fig.1: Map of Lake Burullus showing sampling sites.

\section{Field observations:}

Physico-chemical parameters of water in the selected sites were measured according to APHA (2005). Temperature, electrical conductivity (EC) and total dissolved solids (TDS) were measured by temperature conductivity meter (HANNA instrument, HI 9635). Hydrogen ion concentration $(\mathrm{pH})$ was measured by $\mathrm{pH}$ meter (HI 8543). Dissolved oxygen (DO) was measured by dissolved oxygen meter electrode (HANNA HI 9146).

\section{Water sampling:}

Wate samples were collected in sterilized one-liter polyethylene bottles from each investigated site at $30 \mathrm{~cm}$ below the water surface. Samples were transported in an ice box to the laboratory where they were acidified with concentrated nitric acid $2 \mathrm{ml} / \mathrm{l}$, filtrated through filter papers then syringe-membrane filter pore size $0.45 \mathrm{~mm}$ and kept at $4^{\circ} \mathrm{C}$ till analysis.

\section{Heavy metals analysis:}

Metals stock standards of $\mathrm{Cd}, \mathrm{Pb}, \mathrm{Cu}, \mathrm{Fe}$ and $\mathrm{Zn}$ were used in the determination of heavy metals in water samples using Atomic Absorption Spectrophotometry (AAS) (GBC AVANTA 3000, Australia) and expressed as ppm for copper, zinc and iron using Flame-AAS and as ppb for lead and cadmium using Graphite furnaceAAS, in Environmental Research Laboratory, Theodor Bilharz Research Institute (TBRI). 


\section{Snails and fish sampling:}

Snails were surveyed along the 7 examined sites using a standard dip net (Jobin, 1970 and Yousif et al., 1992). The collected snails from each site were placed in separate plastic aquaria containing water from their habitat and transported to the laboratory for subsequent analysis. Specimens of the Nile tilapia fish "O. niloticus" were collected fresh by the local fishermen from the seven study sites. Blood samples were collected individually in tubes and maintained in an ice box. Each fish was dissected to obtain muscles, gills, liver and kidney that immediately isolated and fixed in $10 \%$ neutral-buffered formalin for $24 \mathrm{~h}$. All samples were transferred to the laboratory for later biochemical and histological investigation.

\section{Snail samples preparation:}

Within $24 \mathrm{~h}$ in the laboratory, snail soft bodies were removed from their shells then washed with distillated water, gently touched filter papers to remove excess water. Some snail soft bodies were weighed then homogenized in bi-distilled water $(1: 1 \mathrm{w} / \mathrm{v})$ using motor homogenizer, and centrifuged at $3000 \mathrm{rpm}$ for $20 \mathrm{~min}$ at $4{ }^{\circ} \mathrm{C}$. The supernatants were taken and kept at $-20^{\circ} \mathrm{C}$ till used for the determination of biochemical parameters. Other snail soft bodies were immediately fixed in aqueous Bouin's fluid [15 ml picric acid (saturated aqueous solution), $5 \mathrm{ml}$ of $40 \%$ formalin, and $1 \mathrm{~mL}$ of $100 \%$ glacial acetic acid] for $24 \mathrm{hrs}$ (Romeis, 1989).

\section{Fish samples preparation:}

The blood samples which collected from fish in tubes free from anticoagulation were centrifuged at $3000 \mathrm{rpm}$ for $15 \mathrm{~min}$ and serum was obtained. Serum was stored in a deep freezer for further biochemical analyses (Smith et al., 2011).

\section{Biochemical assays:}

The collected snail extracted tissues and fish serum samples were used for the determination of the different biochemical parameters using spectrum kits from Egyptian Company for Biotechnology and measured by Spectrophotometer, B.T 224 (Biotechnical instruments). Some parameters were assessed by colorimetric method such as glucose (G) according to Trinder (1969), total protein (TP), albumin (Domas, 1975) and urea (Batton \& Crouch, 1977). While other parameters like creatinine (Young et al., 1975), alkaline phosphatase (ALP) (Belfield and Goldberg, 1971), aspartate aminotransferase (AST), alanine aminotransferase (ALT) activities were detected kinetically as described by Bergmeyer et al. (1986). All parameters in lake samples were compared with that of B. alexandrina snails and $O$. niloticus fish obtained from aquaria that were kept under ideal conditions in the lab and prepared at the same method and time with lake samples as control.

\section{Histological study:}

After fixation of whole snail tissues, paraffin sections were prepared, stained with dyes; hematoxylin and eosin (HE). Histological sections were examined and photographed using ZES microscope with digital camera (Bancroft and Stevens, 1996).

After fixation of the fish organs; muscles, gills, liver and kidney; in 10\% neutral-buffered formalin for $24 \mathrm{~h}$, the tissues were washed in $70 \%$ ethyl alcohol to get rid of excess fixative and dehydrated through ascending grades of ethyl alcohol. Specimens were cleared in xylene for 15-20 min and infiltrated with and embedded in paraffin wax. The paraffin wax blocks were sectioned at 4-6 $\mu \mathrm{m}$ then stained with haematoxylin and eosin according to the method described by (Bernet et al., 1999). 


\section{Statistical Analysis:}

Data were expressed as mean \pm SD. Statistical significance of obtained results was verified using Student's $t$-test and one way ANOVA. All statistical analyses were done using the computer program of SPSS Inc. (2007, version 16.0 for Windows 7).

\section{RESULTS}

\section{Field observations and heavy metals analysis:}

From each site the field observations water temperature, $\mathrm{pH}$, DO, TDS and EC were recorded during samples collection. Results represented in table (1), showed that water temperature range was $23-28^{\circ} \mathrm{C}$, $\mathrm{pH}$ range was $7.02-8.17$, DO range was 4.70- $6.10 \mathrm{mg} / \mathrm{l}$, TDS range was $1111.0-13395.0 \mathrm{mg} / \mathrm{l}$ and EC range was 1400.5$20350.0 \mu \mathrm{mohs} / \mathrm{cm}$. The mean value of the observed temperature and $\mathrm{pH}$ in water samples from the examined lake sites were in the normal range according to permissible limit approved by (USEPA, 2009), while TDS and EC values were exceeded the permissible limit in all the examined sites except in El-Hoksa $1111.0 \pm$ 147.1 and $1400.5 \pm 102.5$, respectively, DO showed slightly lower values than the permissible limit in Khasha and Shakhloba sites (4.7 \pm 0.014 and 4.85 \pm 0.07 , respectively). Results of $\mathrm{Cd}, \mathrm{Pb}, \mathrm{Cu}, \mathrm{Fe}$ and $\mathrm{Zn}$ determination in water samples collected from the lake examined sites are presented in Table (1) in comparison with the level of concern determined by USEPA, 2009. $\mathrm{Cd}, \mathrm{Pb}, \mathrm{Cu}, \mathrm{Fe}$ and $\mathrm{Zn}$ ranged between 0.19- $0.47 \mu \mathrm{g} / \mathrm{l}, 2.01-18.75 \mu \mathrm{g} / \mathrm{l}, 0.017-0.42 \mathrm{mg} / \mathrm{l}, 1.0-20.9 \mathrm{mg} / \mathrm{l}$ and 0.024- $0.38 \mathrm{mg} / \mathrm{l}$, respectively. Lake sites were most polluted with $\mathrm{Pb}(6 / 7$ sites $)$ and the mean value exceeded the permissible level by up to 4.5 times, and Fe (6/7 sites) with mean value 21 times over the concern level followed by $\mathrm{Cd}(5 / 7$ sites) with mean value 1.3 times over the concern level, then $\mathrm{Cu}$ (3/7 sites) with mean value 4.66 times over the concern level, and at last $\mathrm{Zn}$ (3/7 sites) with mean value equal to the concern level. The results showed that the heavy metal levels were determined in lake water with the following order: $\mathrm{Fe}>\mathrm{Zn}>\mathrm{Cu}>\mathrm{Pb}>\mathrm{Cd}$.

Table 1: Physico-chemical parameters recorded in water samples collected from different examined sites in Lake Burullus.

\begin{tabular}{|c|c|c|c|c|c|c|c|c|c|c|c|c|c|c|c|c|}
\hline \multirow[b]{2}{*}{$\begin{array}{l}\text { Physico- } \\
\text { chemical } \\
\text { parameters }\end{array}$} & \multicolumn{4}{|c|}{ El-Hamoul } & \multicolumn{4}{|c|}{ Mottobus } & \multicolumn{2}{|c|}{ Sedi-salem } & \multicolumn{4}{|c|}{ Balttum } & \multirow[b]{2}{*}{$\begin{array}{c}\text { Lake } \\
\text { Burullus }\end{array}$} & \multirow[b]{2}{*}{$\begin{array}{l}\text { P.L. } \\
\text { USEPA } \\
(2009)\end{array}$} \\
\hline & Khasha & 音 & $\begin{array}{l}\text { Bahr- } \\
\text { Tera }\end{array}$ & 救 & Prembal & 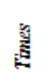 & Hoksa & 糞 & Shakhloba & 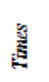 & $\begin{array}{c}\text { El- } \\
\text { Boghaze }\end{array}$ & है & Emad & 氙 & & \\
\hline $\begin{array}{l}\text { Temp } \\
\left({ }^{\circ} \mathrm{C}\right)\end{array}$ & $\begin{array}{l}27.5 \\
\pm 0\end{array}$ & 1.1 & $\begin{array}{c}28.0 \\
\pm 0\end{array}$ & 1.12 & $\begin{array}{c}23.0 \\
\pm 0\end{array}$ & 0.92 & $\begin{array}{c}22.3 \\
\pm 0.07\end{array}$ & 0.89 & $\begin{array}{c}27.5 \\
\pm 0\end{array}$ & 1.1 & $23.5 \quad \pm 0$ & 0.94 & $\begin{array}{c}24.0 \\
\pm 0\end{array}$ & 0.96 & $\begin{array}{c}25.1 \\
\pm 0.63\end{array}$ & $21-25$ \\
\hline $\mathrm{pH}$ & $\begin{array}{l}7.90 \\
\pm 0\end{array}$ & 0.98 & $\begin{array}{c}7.95 \\
\pm 0.07\end{array}$ & 0.99 & $\begin{array}{c}7.48 \\
\pm 0.06\end{array}$ & 0.94 & $\begin{array}{c}7.71 \\
\pm 0.12\end{array}$ & 0.96 & $\begin{array}{c}7.02 \\
\pm 0.02 *\end{array}$ & 0.87 & $\begin{array}{c}7.95 \\
\pm 0.12\end{array}$ & 0.98 & $\begin{array}{c}8.17 \\
\pm 0.04^{*}\end{array}$ & 1.02 & $\begin{array}{c}7.7 \\
\pm 0.1 \\
\end{array}$ & $7-8$ \\
\hline $\begin{array}{c}\text { DO } \\
(\mathrm{mg} / \mathrm{l})\end{array}$ & $\begin{array}{c}4.70 \\
\pm 0.14^{*}\end{array}$ & 0.94 & $\begin{array}{c}5.60 \\
\pm 0.14\end{array}$ & 1.12 & $\begin{array}{c}4.96 \\
\pm 0.08\end{array}$ & 0.99 & $\begin{array}{c}5.06 \\
\pm 0.06\end{array}$ & 1.01 & $\begin{array}{c}4.85 \\
\pm 0.07\end{array}$ & 0.97 & $\begin{array}{c}6.10 \\
\pm 0.14^{*}\end{array}$ & 1.22 & $\begin{array}{l}5.40 \\
\pm 0\end{array}$ & 1.08 & $\begin{array}{c}5.2 \\
\pm 0.13\end{array}$ & $>5$ \\
\hline $\begin{array}{c}\mathrm{TDS} \\
(\mathrm{mg} / \mathrm{L})\end{array}$ & $\begin{array}{c}3006.0 \\
\pm 0\end{array}$ & 2.5 & $\begin{array}{l}3200.0 \\
\pm 989.9\end{array}$ & 2.66 & $\begin{array}{c}1440.5 \\
\pm 31.8\end{array}$ & 1.2 & $\begin{array}{l}1111.0 \\
\pm 147.1\end{array}$ & 0.92 & $\begin{array}{l}1845.0 \\
\pm 21.2\end{array}$ & 1.5 & $\begin{array}{l}13285.0 \\
\pm 1449.5\end{array}$ & 11.1 & $\begin{array}{c}13395.0 \\
\pm 106.1\end{array}$ & 11.2 & $\begin{array}{l}5326.1 \\
\pm 1425\end{array}$ & $400-1200$ \\
\hline $\begin{array}{c}\mathrm{EC} \\
\mu \mathrm{mohs} / \mathrm{cm}\end{array}$ & $\begin{array}{c}4350.0 \\
\pm 70.7\end{array}$ & 3.1 & $\begin{array}{c}4600.0 \\
\pm 1414.2\end{array}$ & 3.28 & $\begin{array}{c}2065.0 \\
\pm 49.5\end{array}$ & 1.47 & $\begin{array}{l}1400.5 \\
\pm 102.5\end{array}$ & 1 & $\begin{array}{c}2670.0 \\
\pm 28.3\end{array}$ & 1.9 & $\begin{array}{c}20350.0 \\
\pm 70.7\end{array}$ & 14.5 & $\begin{array}{c}19150.0 \\
\pm 70.7\end{array}$ & 13.7 & $\begin{array}{c}7796 \\
\pm 2122\end{array}$ & $400-1400$ \\
\hline $\mathrm{Cd}(\mathrm{mg} / \mathrm{l})$ & $\begin{array}{c}0.26 \\
\pm 0.03\end{array}$ & 1.04 & $\begin{array}{c}0.39 \\
\pm 0.15\end{array}$ & 1.56 & $\begin{array}{c}0.31 \\
\pm 0.12\end{array}$ & 1.24 & $\begin{array}{c}0.19 \\
\pm 0.01\end{array}$ & 0.76 & $\begin{array}{l}0.21 \\
\pm 0.2\end{array}$ & 0.84 & $\begin{array}{l}0.47 \\
\pm 0.1\end{array}$ & 1.88 & $\begin{array}{l}0.44 \\
\pm 0.3\end{array}$ & 1.8 & $\begin{array}{l}0.32 \\
\pm 0.2\end{array}$ & 0.25 \\
\hline $\mathrm{Cu}(\mathrm{mg} /)$ & $\begin{array}{c}0.06 \\
\pm 0.06\end{array}$ & 0.66 & $\begin{array}{c}0.017 \\
\pm 0.007\end{array}$ & 0.18 & $\begin{array}{c}0.015 \\
\pm 0.007\end{array}$ & 0.16 & $\begin{array}{c}0.42 \\
\pm 0.26\end{array}$ & 4.66 & $\begin{array}{l}0.035 \\
\pm 0.02\end{array}$ & 0.38 & $\begin{array}{l}0.169 \\
\pm 0.01\end{array}$ & 1.8 & $\begin{array}{c}0.02 \\
\pm 0\end{array}$ & 0.22 & $\begin{array}{l}0.104 \\
\pm 0.16\end{array}$ & 0.09 \\
\hline $\mathrm{Fe}(\mathrm{mg} / \mathrm{l})$ & $\begin{array}{c}1.0 \\
\pm 0.06\end{array}$ & 1 & $\begin{array}{c}11.3 \\
\pm 0.33\end{array}$ & 11 & $\begin{array}{c}9.0 \\
\pm 0.61\end{array}$ & 9 & $\begin{array}{l}20.9 \\
\pm 1.3\end{array}$ & 21 & $\begin{array}{c}3.5 \\
\pm 0.13\end{array}$ & 3.5 & $\begin{array}{c}1.2 \\
\pm 0.004\end{array}$ & 1.2 & $\begin{array}{c}4.8 \\
\pm 0.06\end{array}$ & 4.8 & $\begin{array}{c}7.4 \\
\pm 0.82\end{array}$ & 1.0 \\
\hline $\mathrm{Pb}(\mu \mathrm{g} / \mathrm{l})$ & $\begin{array}{l}11.72 \\
\pm 0.15\end{array}$ & 4.7 & $\begin{array}{l}13.95 \\
\pm 2.6\end{array}$ & 5.6 & $\begin{array}{l}13.40 \\
\pm 0.85\end{array}$ & 5.36 & $\begin{array}{l}13.08 \\
\pm 2.2\end{array}$ & 5.23 & $\begin{array}{l}18.75 \\
\pm 2.8^{*}\end{array}$ & 7.5 & $\begin{array}{c}2.01 \\
\pm 0.2^{*}\end{array}$ & 0.8 & $\begin{array}{l}6.32 \\
\pm 3.3\end{array}$ & 2.5 & $\begin{array}{l}11.32 \\
\pm 5.5 \mathrm{a}\end{array}$ & 2.5 \\
\hline $\mathrm{Zn}(\mathrm{mg} / \mathrm{l})$ & $\begin{array}{c}0.036 \\
\pm 0.005\end{array}$ & 0.3 & $\begin{array}{c}0.19 \\
\pm 0.11\end{array}$ & 1.6 & $\begin{array}{c}0.027 \\
\pm 0.004\end{array}$ & 0.22 & $\begin{array}{l}0.024 \\
\pm 0.03\end{array}$ & 0.2 & $\begin{array}{c}0.38 \\
\pm 0.53\end{array}$ & 3.2 & $\begin{array}{c}0.04 \\
\pm 0.02\end{array}$ & 0.33 & $\begin{array}{l}0.168 \\
\pm 0.1\end{array}$ & 1.4 & $\begin{array}{c}0.12 \\
\pm 0.16\end{array}$ & 0.12 \\
\hline
\end{tabular}

Physical parameters as mean \pm standard deviation $\quad$ P.L. $=$ Permissible limits.

$*, * *$ and $* * * \mathrm{P}<0.05,0.01$ and 0.001 respectively in comparison between different lake sites. 


\section{Biochemical studies:}

Results of biochemical parameters (mean \pm SD) that determined in $B$. alexandrina snails are shown in Table (2). The present results showed highly significant increase in AST, ALT and ALP in Shakhloba and Khasha sites while Mottobus samples showed insignificant increase. As well, all snail samples showed highly significant increase in total protein, albumin level and glucose. On the other hand, A/G ratio was in the normal range of (1.17-1.33), creatinine showed significant decrease, and urea was ranged between normal to insignificant increase. So, most of the examined biochemical parameters indicated affected liver, and Shakhloba samples in Sidi-Salem center was the most affected followed by Khashaa samples in El-Hamoul center while Prempal samples in Mottobus center was the least

Table 2: Means \pm SD measurements of biochemical components taken from $B$. alexandrina snail collected from different sites at Lake Burullus.

\begin{tabular}{|c|c|c|c|c|c|c|c|}
\hline $\begin{array}{c}\text { Biochemical } \\
\text { parameters }\end{array}$ & control & $\begin{array}{c}\text { El- } \\
\text { Hamoul }\end{array}$ & $\begin{array}{c}\% \text { of } \\
\text { Change }\end{array}$ & Mottobus & $\begin{array}{c}\% \text { of } \\
\text { Change }\end{array}$ & $\begin{array}{c}\text { Sidi- } \\
\text { Salem }\end{array}$ & \% of Change \\
\hline $\begin{array}{l}\text { AST } \\
(\mathbf{U} / \mathbf{L})\end{array}$ & $\begin{array}{c}32.75 \\
\pm 2.5\end{array}$ & $\begin{array}{c}91.00 \\
\pm 7.0 * *\end{array}$ & 177 & $\begin{array}{c}61.00 \\
\pm 4.0\end{array}$ & 86 & $\begin{array}{c}103.5 \\
\pm 8.5 * * *\end{array}$ & 216 \\
\hline $\begin{array}{l}\mathbf{A L T} \\
(\mathbf{U} / \mathbf{L})\end{array}$ & $\begin{array}{c}87.08 \\
\pm 11.04\end{array}$ & $\begin{array}{l}199.0 \\
\pm 4.0 *\end{array}$ & 129 & $\begin{array}{c}98.50 \\
\pm 3.5\end{array}$ & 13 & $\begin{array}{l}181.0 \\
\pm 4.0 *\end{array}$ & 108 \\
\hline $\begin{array}{l}\text { ALP } \\
\text { (IU/L) }\end{array}$ & $\begin{array}{c}85.64 \\
\pm 8.6\end{array}$ & $\begin{array}{l}170.0 \\
\pm 6.0 *\end{array}$ & 98 & $\begin{array}{l}99.0 \\
\pm 3.0\end{array}$ & 16 & $\begin{array}{c}188.0 \\
\pm 4.0 * *\end{array}$ & 120 \\
\hline $\begin{array}{l}\text { TP } \\
(\mathrm{g} / \mathrm{dl})\end{array}$ & $\begin{array}{l}1.745 \\
\pm 0.25\end{array}$ & $\begin{array}{c}7.750 \\
\pm 1.15 * *\end{array}$ & 344 & $\begin{array}{c}7.40 \\
\pm 0.30 * *\end{array}$ & 324 & $\begin{array}{c}9.10 \\
\pm 0.60 * * *\end{array}$ & 421 \\
\hline $\begin{array}{l}\text { Alb } \\
\text { (g/dl) }\end{array}$ & $\begin{array}{c}1.01 \\
\pm 0.09\end{array}$ & $\begin{array}{c}4.25 \\
\pm 0.85 *\end{array}$ & 320 & $\begin{array}{c}4.15 \\
\pm 0.35 *\end{array}$ & 311 & $\begin{array}{c}4.65 \\
\pm 0.95\end{array}$ & 360 \\
\hline $\begin{array}{l}G \\
(g / d l)\end{array}$ & $\begin{array}{c}0.74 \\
\pm 0.16 \\
\end{array}$ & $\begin{array}{l}3.50 \\
\pm 0.3 \\
\end{array}$ & 370 & $\begin{array}{c}3.25 \\
\pm 0.65\end{array}$ & 339 & $\begin{array}{l}4.30 \\
\pm 1.4\end{array}$ & 481 \\
\hline $\begin{array}{l}\text { A/G } \\
\text { Ratio }\end{array}$ & $\begin{array}{r}2.30 \\
\pm 1.1\end{array}$ & $\begin{array}{c}1.20 \\
\pm 0.14\end{array}$ & -48 & $\begin{array}{c}1.33 \\
\pm 0.35\end{array}$ & -42 & $\begin{array}{c}1.26 \\
\pm 0.67\end{array}$ & -45 \\
\hline $\begin{array}{l}\text { Glu } \\
\text { (mg/l) }\end{array}$ & $\begin{array}{c}\mathbf{5 7 . 5 0} \\
\pm 3.5\end{array}$ & $\begin{array}{c}\mathbf{9 7 . 5 0} \\
\pm 5.5 * * *\end{array}$ & 70 & $\begin{array}{c}88.00 \\
\pm 1.0 * *\end{array}$ & 53 & $\begin{array}{c}92.00 \\
\pm 3.0 * *\end{array}$ & 60 \\
\hline $\begin{array}{l}\text { Creat } \\
(\mathrm{mg} / \mathrm{dl})\end{array}$ & $\begin{array}{c}0.59 \\
\pm 0.05\end{array}$ & $\begin{array}{c}0.29 \\
\pm 0.07 * *\end{array}$ & -51 & $\begin{array}{c}0.37 \\
\pm 0.03 *\end{array}$ & -37 & $\begin{array}{c}0.30 \\
\pm \mathbf{0 . 0 2} * *\end{array}$ & -49 \\
\hline $\begin{array}{l}\text { Urea } \\
(\mathrm{mg} / \mathrm{dl})\end{array}$ & $\begin{array}{c}11.00 \\
\pm 1.0\end{array}$ & $\begin{array}{c}10.00 \\
\pm 1.0\end{array}$ & -9 & $\begin{array}{c}17.00 \\
\pm 1.0\end{array}$ & 54 & $\begin{array}{c}12.50 \\
\pm 0.5\end{array}$ & 14 \\
\hline
\end{tabular}

Biochemical parameters (mean $\pm \mathrm{SD}$ ) of O. niloticus collected from 7 sites at Lake Burullus are shown in Table (3). Samples from all sites showed increase in AST \& ALP, the most increase was in Shakhloba and Bahr Tera sites with percentage change equal to $268 \& 92 \%$ and $222 \& 115 \%$, respectively. Samples from all sites showed slight decrease in ALT \& Glu with percentage change ranged between "-25 to $-58 \%$ " \& "-4 to $-30 \%$ ", respectively. All sites showed increase in total protein, significances $(\mathrm{P}<0.01 \& \mathrm{P}<0.05)$ were exhibited in Bahr Tera site and in the mean value for all sites, respectively. Only Shakhloba and Bahr Tera showed reversed A/G ratio while the mean value of all sites showed high normal ratio. Urea showed slight decrease with percentage change ranged between -15 to $-36 \%$ in all sites except for Shakhloba that showed slight increase with percentage change equal to $20 \%$. Creatinine increased in all sites and only significance was exhibited in Shakhloba site. The same as recorded in snail samples, most of the examined biochemical parameters indicated affected liver, and Bahr Tera site in El-Hamoul center and Shakhloba site in Sidi-Salem were the most while Prempal in Mottobus center was the least. 
Table 3: Means \pm SD measurements of biochemical serum components taken from Nile tilapia $(O$. niloticus) collected from different sites at Lake Burullus.

\begin{tabular}{|c|c|c|c|c|c|c|c|c|c|c|c|c|c|c|c|c|c|}
\hline \multirow{2}{*}{$\begin{array}{l}\text { Biochemical } \\
\text { parameters }\end{array}$} & \multirow[b]{2}{*}{ control } & \multicolumn{4}{|c|}{ El-Hamoul } & \multicolumn{4}{|c|}{ Balteem } & \multicolumn{4}{|c|}{ Mottobus } & \multicolumn{2}{|c|}{ Sidi-Salem } & \multicolumn{2}{|c|}{ El-Burullus } \\
\hline & & Khaska & $\begin{array}{c}\% \text { of } \\
\text { change }\end{array}$ & $\begin{array}{l}\text { Bahr- } \\
\text { Tera }\end{array}$ & $\begin{array}{c}\% \text { of } \\
\text { change }\end{array}$ & $\begin{array}{c}\text { El- } \\
\text { Boughaz }\end{array}$ & $\begin{array}{c}\% \text { of } \\
\text { change }\end{array}$ & Emad & $\begin{array}{c}\% \text { of } \\
\text { change }\end{array}$ & Prembal & $\begin{array}{c}\% \text { of } \\
\text { change }\end{array}$ & Hoksa & $\begin{array}{c}\% \text { of } \\
\text { Change }\end{array}$ & Shakhloba & $\begin{array}{c}\% \text { of } \\
\text { Change }\end{array}$ & Mean & $\begin{array}{c}\% \text { of } \\
\text { Change }\end{array}$ \\
\hline $\begin{array}{l}\text { AST } \\
(\mathrm{U} / \mathrm{L})\end{array}$ & $\begin{array}{l}33.7 \\
\pm 7.6\end{array}$ & $\begin{array}{r}75.50 \\
\pm 12.02\end{array}$ & 124 & 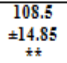 & 222 & $\begin{array}{l}85.00 \\
\pm 11.31\end{array}$ & 152 & $\begin{array}{l}85.50 \\
\pm 23.33\end{array}$ & 154 & $\begin{array}{l}42.00 \\
\pm 4.24\end{array}$ & 25 & $\begin{array}{c}91.5 \\
\pm 14.85\end{array}$ & 172 & $\begin{array}{c}124.0 \\
\pm 19.80 * * *\end{array}$ & 268 & $\begin{array}{c}87.43 \\
\pm 27.31 * *\end{array}$ & 159 \\
\hline $\begin{array}{c}\text { ALP } \\
\text { (IU/L) }\end{array}$ & $\begin{array}{c}47.4 \\
\pm 11.15\end{array}$ & $\begin{array}{r}90.50 \\
\pm 38.89\end{array}$ & 91 & $\begin{array}{l}102.00 \\
\pm 14.14 \\
\vdots\end{array}$ & 115 & $\begin{array}{l}\mathbf{5 9 . 5 0} \\
\mathbf{9 7 . 7 8}\end{array}$ & 26 & $\begin{array}{l}64.00 \\
\pm 8.48\end{array}$ & 35 & $\begin{array}{r}59.50 \\
\pm 10.61\end{array}$ & 26 & $\begin{array}{l}59.00 \\
\pm 2.82\end{array}$ & 24 & $\begin{array}{r}91.00 \\
\pm 18.38\end{array}$ & 92 & $\begin{array}{l}75.07 \\
\pm 22.3\end{array}$ & 58 \\
\hline $\begin{array}{l}\text { Alb } \\
\text { (g/dl) }\end{array}$ & $\begin{array}{l}1.97 \\
\pm 0.18\end{array}$ & $\begin{array}{r}4.10 \\
=1.55\end{array}$ & 108 & $\begin{array}{l}5.25 \\
\pm 0.07 *\end{array}$ & 166 & $\begin{array}{c}4.65 \\
\pm 0.63 \text { * }\end{array}$ & 136 & $\begin{array}{r}4.05 \\
\pm 0.49\end{array}$ & 106 & $\begin{array}{c}3.30 \\
=0.85\end{array}$ & 68 & $\begin{array}{c}3.85 \\
\pm 1.06\end{array}$ & 95 & $\begin{array}{c}4.70 \\
\pm 1.27 \text { * }\end{array}$ & 139 & $\begin{array}{c}4.27 \\
\pm 0.94 * * *\end{array}$ & 117 \\
\hline $\begin{array}{c}\mathrm{G} \\
(\mathrm{g} / \mathrm{dl})\end{array}$ & $\begin{array}{l}0.92 \\
2.8 \pm \\
\end{array}$ & $\begin{array}{c}2.65 \\
\pm 0.63 \\
\end{array}$ & 188 & $\begin{array}{c}1.75 \\
\pm 0.35 \\
\end{array}$ & 90 & $\begin{array}{l}2.85 \\
\pm 1.2\end{array}$ & 210 & $\begin{array}{l}2.55 \\
\pm 0.3\end{array}$ & 177 & $\begin{array}{c}2.70 \\
\pm 0.57\end{array}$ & 193 & $\begin{array}{l}2.60 \\
\pm 0.7\end{array}$ & 183 & $\begin{array}{r}1.90 \\
\pm 0.42\end{array}$ & 107 & $\begin{array}{r}2.43 \\
\pm 0.63 \\
\end{array}$ & 164 \\
\hline $\begin{array}{l}\mathrm{A} / \mathrm{G} \\
\text { Ratio }\end{array}$ & $\begin{array}{c}0.89 \mathrm{~N} \\
\pm 0.3\end{array}$ & $\begin{array}{c}1.66 \\
\pm 0.98\end{array}$ & $\mathrm{~N}$ & $\begin{array}{c}3.60 \\
\pm 0.14^{*}\end{array}$ & H & $\begin{array}{c}1.84 \\
\pm 1.00\end{array}$ & $\mathrm{~N}$ & $\begin{array}{c}1.62 \\
\pm 0.42 \\
\end{array}$ & $\mathrm{~N}$ & $\begin{array}{c}1.28 \\
\pm 0.58\end{array}$ & $\mathbf{N}$ & $\begin{array}{c}1.59 \\
\pm 0.84 \\
\end{array}$ & $\mathbf{N}$ & $\begin{array}{c}2.61 \\
\pm 1.26 \\
\end{array}$ & H & $\begin{array}{c}2.02 \\
\pm 0.98 \\
\end{array}$ & $\mathrm{HN}$ \\
\hline
\end{tabular}

Mean values \pm standard deviation. $\quad *, * *$ and $* * *$ significance level $(\mathrm{P}<0.05,0.01$ and 0.001$)$ respectively.

\section{Histological studies:}

The normal foot region has an outer cuticle layer as a protective layer of the foot. Inner to this lining there is a tall columnar epithelium with basal nuclei in its cell. Amongst the columnar epithelium there are modified sacs like cells in the form of unicellular glands which open through the cuticular layer exterior to the foot surface. These unicellular glands are involved in mucous secretion. Embedded inbetween there are transversely muscle fibers, called as longitudinal muscle fibers. Major part of the foot muscles are made up of thickly arranged oblique muscle fibers (Plate 1A). Histopathological observations in foot region of snail samples showed splitting of the oblique muscle fibers and increased empty spaces in samples collected from Prembal site (Plate 2A) and edema, vaculation, necrotic change and darkening in outer layer due to heavy metals accumulation were shown in samples collected from Khasha and Bahr-Tera (Plate 1C\&D). Also, results showed vaculation and necrotic change in the mucous secreting unicellular glands ((Plate 1E) in samples collected from Shakhloba site.

The normal histological structure of Biomphalaria hepatopancreas includes glandular tubules interspersed with connective tissues. The entire gland is enclosed within a thin-walled sac called as tunica propria. The hepatopancreatic epithelium is rested on thin basement membrane; at least 3 types of cells can be recognized in the hepatopancreatic epithelium of the snail, digestive, calcium and excretory cells (Plat 2A). The histopathological changes showed vacuolation and cellular necrosis followed by loss of secretory activity of the epithelial cells in Prembal samples (Plat 2B). The samples collected from Khasha site showed severe vacuolar degeneration of digestive gland with focal areas of necrosis ((Plat 2C). Dilated lumen and more than two hepatopancreatic tubules connected together with one larger lumen in Bahr-Tera samples ((Plat 2D). Also, atrophy, heavy metals accumulated in the basement membrane, degeneration, and fat vacuolation were noticed in Shakhloba samples ((Plat 2E). The B. alexandrina hermaphrodite gland consists of large number of acini that are connected together with a connective tissue. The acini are lined with distinct germinal epithelium composed of cuboidal and flattened cells. This epithelium gives rise to spermatogenesis and oogenesis. The male cells are differentiated forming primary and secondary spermatocytes. The female oogonia cells are usually arranged along the periphery of the acinus as primary, secondary 
oocytes and mature ova. Developed sperms were observed in the lumen of the acinus, each has an oval small head and thread like long tail. Each acinus contains 1-2 mature ova, while sperms aggregated in large numbers inside the lumen (Plate 3A). Histopathological alteration in Mottobus samples showed Atrophy and reduction in the number of sperms (Plate 3B). Khashaa sample showed vacuolation and atrophy of different stage of sperm (Plate 3C). Degenerative changes were observed in most of the ova, where some of them lost their normal shape in sample collected from Bahr-Tera (Plate 3D). Some acini appear- more or less- evacuated and large fat vacuoles can be seen in Shakhloba samples ((Plate 3E).

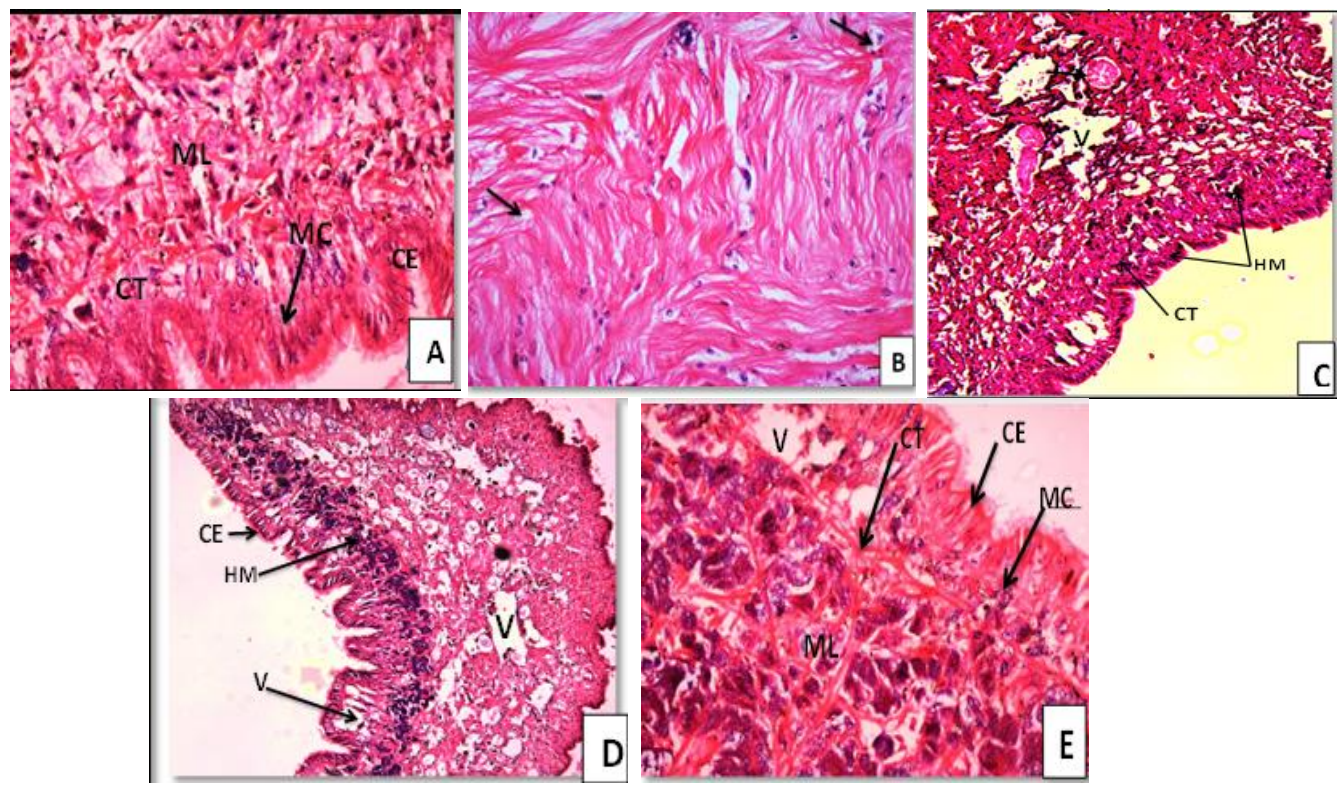

Plate 1: Head foot of Biomphalaria alexandrina [A] showing control connective tissue (CT), mucous cell (MC); muscle layer (ML) and columnar epithelia (CE). [B]: Oblique muscle fiber got splitting and focal areas of necrosis (X200). [C]: Empty spaces or vacuoles (V) within muscle and darkened in outer layer (HM) (X 100). [D]: Observed vacuoles (V) within muscle, edema and darkened in outer layer. (X200). [E]: showing empty spaces or vacuoles (V) within muscle and shrinkage in the mucous secreting unicellular glands (H\&E X 400).
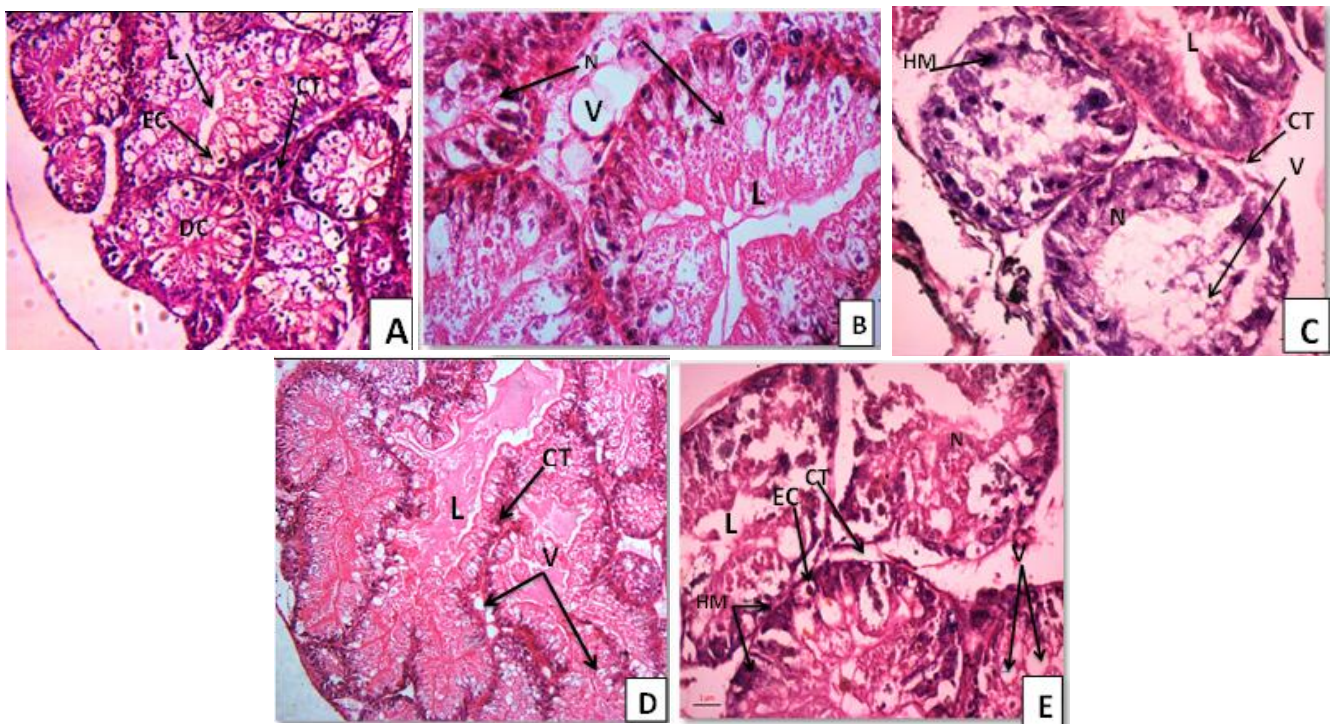

Plate 2: Digestive gland of B. alexandrina [A]: Showing control Lumen (L); digestive cell (DC); excretory cells (EC), and connective tissue (CT) between hepatopancreatic tubules [B] vaculation (V) and necrotic change in digestive cell $(\mathrm{N})$. [C]: degeneration and fat vaculation $(\mathrm{V})$ and necrotic change of tubules cells (N) and accumulation of heavy metals in basement membrane (HM) (X 400). [D]: showing dilated lumen and more than two tubules connected together with one larger lumen (X 100). [E]: Atrophy, vacuolar degeneration, heavy metals accumulation and necrotic change of tubules cells (X400). 


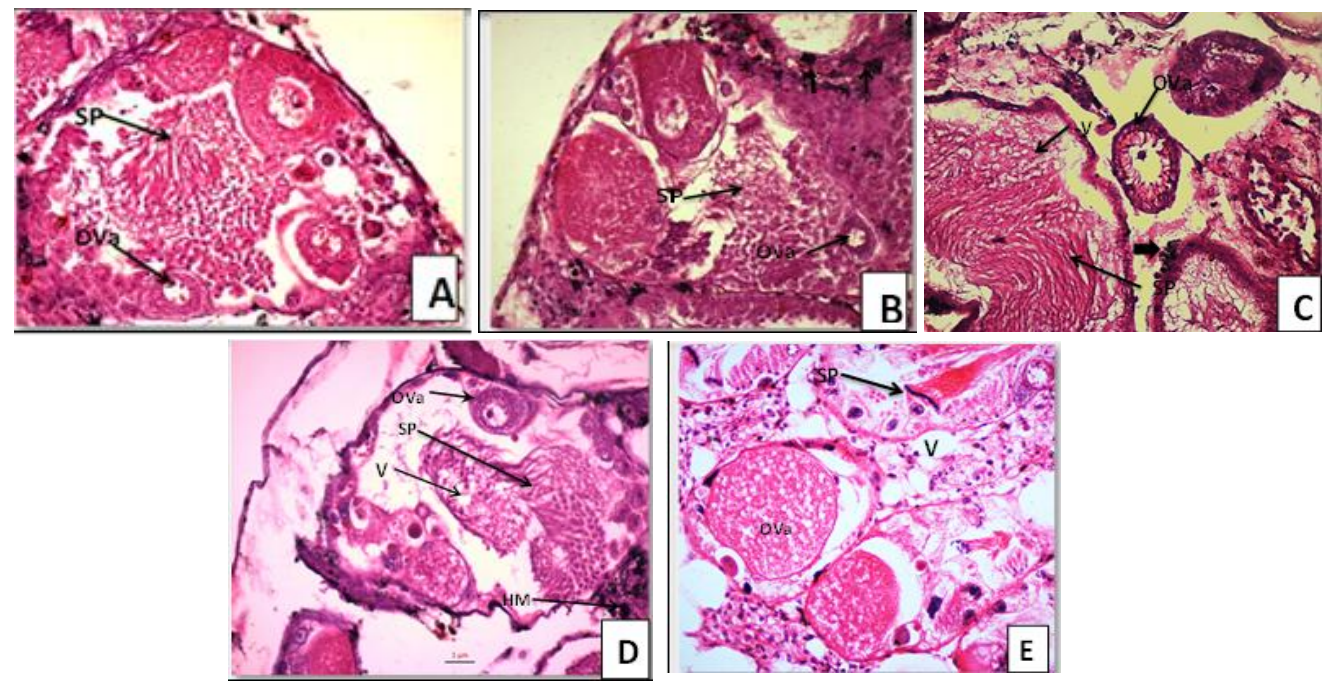

Plate 3: Hermaphrodite gland of Biomphalaria alexandrina [A]: Showing control sperm (SP), and Ova (Ova). [B]: showing atrophy and reduction in the number of sperms (SP), and absorption of oocytes (Ova). [C]: Vacuolation and atrophy of different stages of sperm (V), necrotic spermtogonia and accumulation of heavy metals (short arrows) (X 400). [D]: ova lost their normal shape and reduction in the number of sperms was noticed (X400). [E]: large fat vacuoles and severe necrotic change(X400).

The normal histological structures of the muscle of $O$. niloticus are shown in Plate (4A). Several pathological lesions were seen in the muscle of the examined fish, included splitting of muscle bundles with sever edema in muscle of fish collected from prembal site (Plate 4B) with hemosiderin adhering to vein wall and lymphocyte infiltration and necrotic change between bundles (Plate 4C\&D) in fish collected from Bahr-Tera and Khashaa sites. Also, vacuolar degeneration in muscles bundles and aggregations of inflammatory cells between the muscle bundles in fish collected from Shakhloba site (Plate 4E). Alternations were more sever in muscle of studied fish collected from El-Hamoul sites followed by Sidi-Salem site.


Plate 4: Histopathological alterations in the muscles of the Nile tilapia $[A]$ : Normal histological structure of muscles bundles (MB). [B]: splitting of muscle fiber (SM) and showing necrotic change between bundles $(\mathrm{N})(\mathrm{x} 400)$. [C]: Showing hemosiderin $(\mathrm{H})$ adhering to vein wall, sever splitting in muscles fibers (SM) and hyaline degeneration with lymphocyte infiltration (LC) (X400). [D]: showing severs splitting in muscles fibers (SM) and aggregation of lymphocytes infiltration (LC) (X100) [E]: vacuolar degeneration in bundles (V), mild splitting muscles fibers (SM). Aggregations of inflammatory cells between the muscle bundles (LC).H\&E (X: 400). 
The gill consists of filaments covered by a stratified epithelium called filamental epithelium. Each filament has a series of gill lamellae that are located perpendicular to the filament; they represent the actual respiratory surfaces.

The gill lamellae are lined with the lamellar epithelium which consists of a single or double layer of simple squamous epithelial cells; pavement cells and narrow supporting cells; pillar cells which enclose capillary blood channels that are filled with erythrocytes. These are contractile cells to regulate the blood flow. The epidermis of the gill filament contains numerous mucous cells with opaque cytoplasm. Chloride cells are common at the bases of the lamellae; they are involved in ion regulation with a possible role in detoxification (Plate 5A).

The light microscopy examination of the sections of the gills of fish samples collected from different sites along the lake showed some structural changes. It was obvious that the histopathological alternations of the gills were more or less similar in the investigated sites, however they differ in their degree of severity from mild as it was recorded in sections of gills obtained from the fish samples of the Prembal site to totally damaged like that was noticed in the samples from El-Hamoul and Sidi-Salem sites. These lesions included cellular and circulatory changes. The cellular alterations revealed shortening, atrophy and curling in the lamellae. Lamellar interstitial edema was observed. This edematous change led to the epithelial lifting of the gill lamellae. Hypertrophy of the chloride and mucous cells was also observed. Epithelial hyperplasia of the gill filament was clearly seen. These alterations led to fusion of the neighboring lamellae.

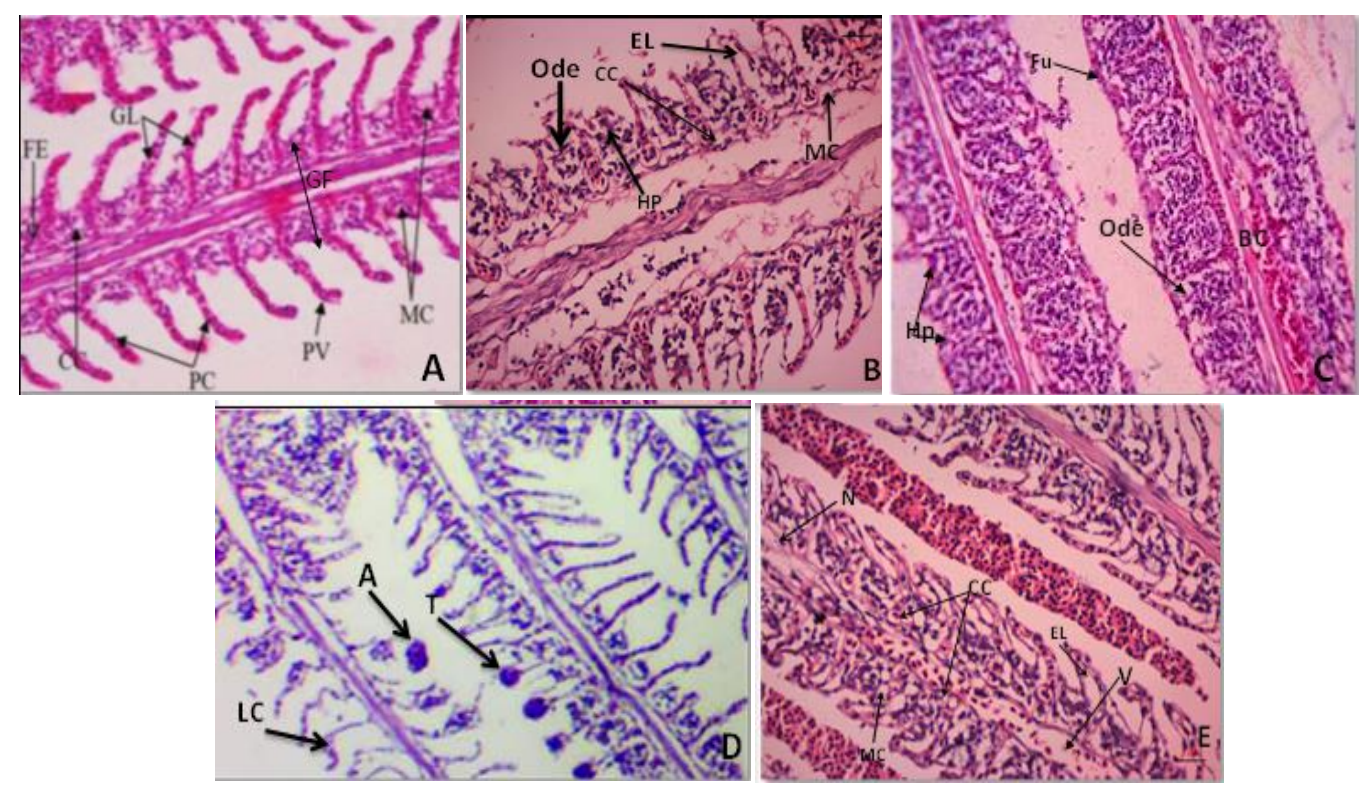

Plate 5: Photomicrographs of the gills of Oreochromis niloticu[A]: Showing the normal structure. Notice the gill filament (GF), the gill lamellae (GL), the chloride cells (CC), the pillar cells (PC), the pavement cells (PV) and the mucous cells (MC). [B]: showing epithelial lifting (EL) and separated epithelial cells from basement membrane. (X400)[C]: Observed blood congestion (BC), hyperplasia (Hp), fusion (Fu) of the gill lamellae and interstitial oedema (Ode) of the gill lamellae (x400). [D]: showing oedema in the epithelium of gill filament, aneurism (A), lamellar curling (LC) and telangiectasis (T). [E]: Showing mucous cell (MC), chloride cell (CC), epithelial lifting (EL), vasodilation (V) with blood congestion (BC) and necrosis in the epithelium of the gill filament (N) (X 400).

Necrosis and epithelial degeneration occasionally occurred. However, the circulatory disturbances showed lamellar clubbed tips, vasodilation in the gill 
filaments with blood congestion. Rupture of the pillar cells and capillaries resulted in small purple clusters showing telangiectasis.

Also, aneurism was observed in the gill sections. Aneurism was resulted due to the abnormal widening or ballooning of the marginal blood capillaries of the gills (Plate 5 B-E).

Normal structure of the liver of the control tilapia fish (Plate 6A), the histological examination of the normal liver tissue shows that the hepatocytes are polygonal cells with a central spherical nucleus and a densely stained nucleolus. These liver cells form cords that are separated by capillary sinusoids radiating from a central vein. The cytoplasm of the hepatocytes may normally contain vacuoles to store the lipids and glycogen which are related to the normal metabolic function of the liver. There are the pancreatic tissues in the form of randomly-scattered pancreatic acini that are embedded in the hepatic tissue and in close contact with the hepatocytes. The histological alterations of the collected liver samples were distortion, dilation and congestion of the blood vessels and sinusoids. In addition to irregular arrangements of hepatocytes that resulted in loss of its characteristic architecture. There was cytoplasmic vacuolation in the liver cells. Different levels of degenerative and necrotic changes were also observed. The presence of the pyknotic nuclei was one of the most frequent and marked changes revealed almost in liver tissues of all samples collected from different sites. The extracellular spaces showed marked wideness and loss of the contact between hepatocytes and pancreatic acini due to degeneration of the hepatocytes around the pancreatic tissue, degeneration of many pancreatic cells and congestion of the pancreatic blood vessel, especially in the liver of the fish samples collected from Khashaa and Shakhloba (Plate 6 D\&E).

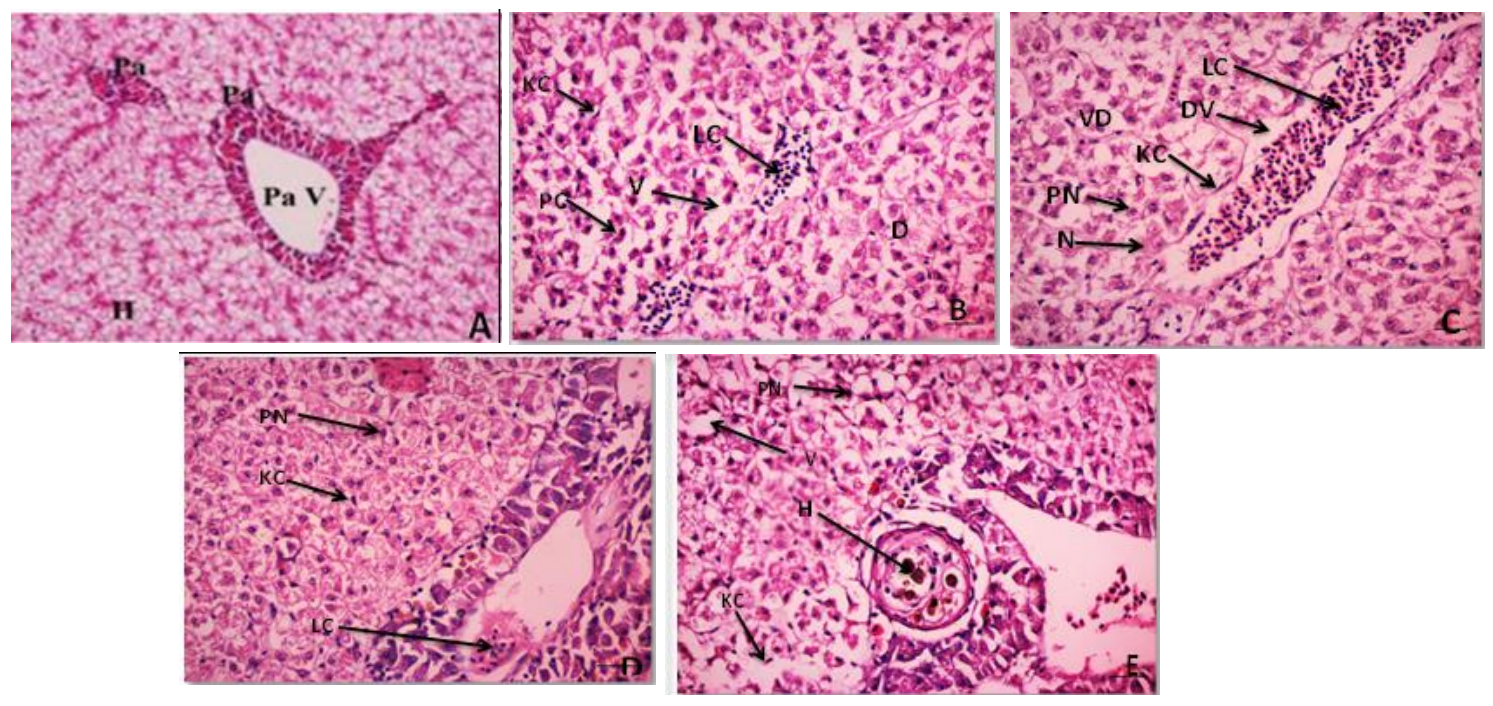

Plate 6: photomicrograph showing the normal histological structure of the liver of Oreochromis niloticus. [A]: Notice the normal hepatocytes $(\mathrm{H})$ and the pancreatic tissue or acini $(\mathrm{Pa})$ embedded in the liver tissue and the pancreatic blood vessel (Pa V). [B]: Showing lymphocyte infiltration (LC), hepatic vacuolar (V), degeneration (D), pycnotic nuclei (PN) and kupffer cells (KC) H\&E (X 400). $[C]$ : Showing dilated veins (DV) with lymphocyte infiltration (LC), focal area of necrosis $(\mathrm{N})$, vacuolar degeneration (VD), pycnotic nuclei (PN) and kupffer cells (KC) )(X400). [D]: showing pancreatic asnius with moderate lymphocyte change (LC), necrotic change, pycnotic nuclei (PN) and kupffer cells $(\mathrm{KC})$. [E]: showing atrophy of hepatic asunioside cells of around parasite granular, necrotic change, hemosiderin $(\mathrm{H})$, hepatic vacuolar $(\mathrm{V})$, pycnotic nuclei $(\mathrm{PN})$ and kupffer cells $(\mathrm{KC})$ (X400).

Infiltration of inflammatory cells, hemorrhage inside the blood vessels and hypertrophy of Kupffer cells were also noticed in the liver of the fish samples 
collected from Bahr- Tera (Plate 6C). These histopathological changes were markedly severe in El-Hamoul sites more than the alterations that were observed in Sidi-Salem site followed by Mottobus site.

The kidney was composed of numerous renal corpuscles with well-developed glomeruli and a system of tubules. The proximal segment was covered by tall columnar epithelial cells with basal nuclei and brush border located along the cell apices. The distal segment was lined with large, relatively clear columnar epithelial cells with central nuclei and the brush border was reduced or absent. The collecting duct or glomerulus was larger in diameter than the distal segment, containing columnar epithelial cells with basal nuclei and no brush border. Histological study shows a typical structural organization of the kidneys in the control fish (Plate 7A). The histo-pathological alternations of the kidney included sever degeneration in renal tubules with increasing in nuclei of lymphatic cells between tubules; some tubular epithelial cells are vacuolated and separated from the basement membrane resulting from edema. Necrotic changes in tubules and shrinking in glomerulus in bowmen's capsule or complete disappearance. Edema in Bowman's capsule also showed hemosiderin and lymphocytic infiltration in renal tubules (Plate 7B-E). Generally, kidney in all sites of the Lake Burullus was destroyed because it is one of the first organs affected by contaminants in the water.

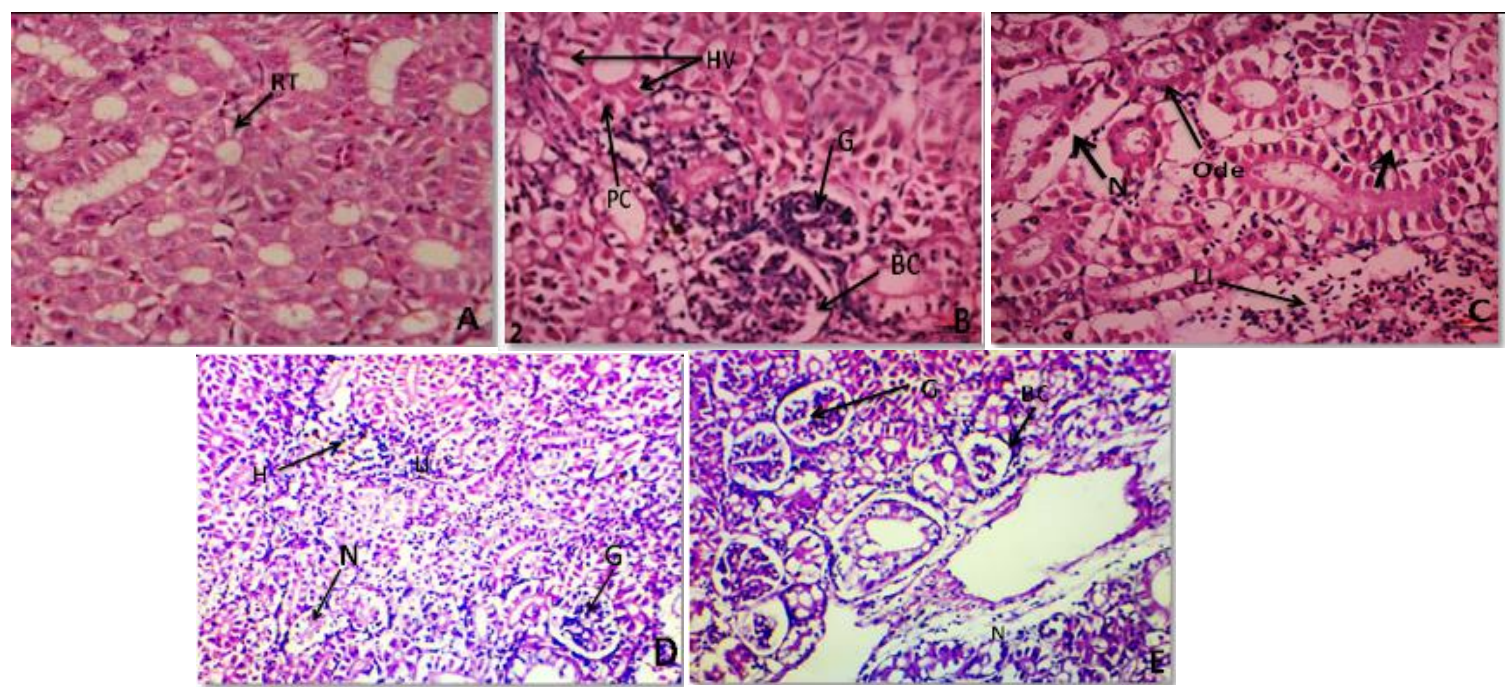

Plate 7: Photomicrographs of the kidney of O. niloticus [A]: Normal renal corpuscle showing renal tubules (RT). [B]: Glomerular expansion (G), dilation of Bowman's space and necrosis (BC), hydropic vaculation in renal tubules $(\mathrm{HV})$, pycnotic nuclei $(\mathrm{PN})$ and hemosiderin $(\mathrm{H}) . \quad[\mathrm{C}]$ : Showing lymphatic infiltration between renal tubules $(\mathrm{Li})$, necrosis in the renal tubules $(\mathrm{N})$, oedema (Ode) and vacuolation in tubular cell (arrow) (H\&E X400). [D]: showing hemosiderin $(\mathrm{H})$, lymphocytic infiltration $(\mathrm{Li})$ in renal tubules, shrinking in glomerulus $(\mathrm{G})$ and showing necrotic change $(\mathrm{N})(\mathrm{X} 100)$. [E]: edema in Bowman's capsule (BC) and shrinking in glomerulus $(\mathrm{G})$, necrotic change in renal tubules $(\mathrm{N})(\mathrm{X} 400)$.

\section{DISCUSSION}

Healthy lakes and their shores not only provide us with a number of environmental benefits but they influence our quality of life and they strengthen our economy. Lakes constitute important habitats and food resources for a diverse array of fish, aquatic life, and wildlife, but lake ecosystems are fragile. Lake Burullus has received a great attention because of its economic importance for being a significant source of fish production in Egypt. The lake water quality is affected by discharge of 
seven agricultural drains containing agricultural, industrial, and domestic wastewaters without any pre-treatment, (Zaghloul et al., 2007; Nafea and Zyad, 2015; Emara et al., 2016 and El-Batrawy et al., 2018). Several authors studied O. niloticus fish and B. alexandrina snails as bio-indicators for water pollution (Abd El-Aziz et al., 2011; Abdel-Moneim et al., 2012; El-Khayat et al., 2015a \& 2016 and El-Batrawy et al., 2018). Freshwater snails play an important role in aquatic ecosystems, providing food for many fish species and vertebrates) Maltchik et al., 2010). Fish are located at the end of the aquatic food chain and may accumulate metals and pass them to human beings through consumption causing chronic or acute diseases, (Al-Yousuf et al., 2000).

The observed water quality criteria in the present work; water temperature, $\mathrm{pH}$ and DO; were in normal range in most of lake sites suggesting their little impacts on the biological processes and survival of lake fauna. Temperature and DO are important factors in the aquatic environment since they affect their biological processes and susceptibility to diseases and distribution (Tayel et al., 2008 and Moustafa et al., 2010). Among the studied sites in Lake Burullus, Khashaa and Shakhloba sites showed the least values of DO this may be attributed to these sites are near to the discharge points of drains station $7 \&$ station 8 , respectively, while ElBughaz Intel site showed the highest DO value suggesting the dilution role of seawater in the improvement of lake water quality in this site. These findings are in consequence with that of Zaghloul et al. (2007) who recorded higher value of DO content at El-Boughaz inlet than that observed in eastern and western sectors, the much suffered from the industrial and agricultural discharge causing high levels of organic, inorganic salts and heavy metals that lead to fish hypoxia. The present $\mathrm{pH}$ values were slightly lie on alkaline side, this is may be related to the photosynthetic activity of phytoplankton and other aquatic plants, (Emara et al., 2016, Tayel et al., 2014 and Gohera et al., 2017). Regarding to the present results of EC and TDS values, they were exceeded the permissible limits that determined by United States Environmental Protection Agency (USEPA, 2009) in all the examined sites, this may be attributed to natural factors like the evaporation rate, land run off which contains large amounts of cations and anions, and anthropological factors like non-treated agricultural wastewater. It was found that $\mathrm{Pb}$ and $\mathrm{Fe}$ exceeded the concern level several times in most lake sites. Shakhloba and Hoksa sites the nearer to the drains station No. 8, 9 and drain No 11, respectively, showed the highest heavy metal levels and followed by Bahr-Tera site (in close to station No. 7 drain), Permbal site (in close to Prembal canal from The River Nile) then Khashaa site (in close to Gharbia drain). El-Boughaz and Emad sites the nearer to the sea through Boughaz inlet showed the lowest level of most heavy metals. The present high lake heavy metal levels may be also attributed to gasoline motors, industrial, agricultural effluents and municipal sewage contamination which is rich with fertilizers and chemicals that feeds the lake as previously reported by Gad (2005) and Emara et al. (2016). The present study showed approximately the same the mean levels of $\mathrm{Cu}, \mathrm{Fe}, \mathrm{Zn}$ and $\mathrm{Pb}$ $(0.104,7.4,0.12 \mathrm{mg} / \mathrm{l}$ and $11.32 \mu \mathrm{g} / \mathrm{l}$, respectively) as levels recorded in Lake Burullus by Saeed \& Shaker (2008) ( $\mathrm{Zn}$ and $\mathrm{Pb}$ equal to $0.1 \mathrm{mg} / \mathrm{l}$ and $6.5 \mu \mathrm{g} / \mathrm{l}$, respectively) and Nafea \& Zyada, (2015) (Pb range equal to 4.3-10.1 $\mu \mathrm{g} / \mathrm{l})$. While were higher than a study reported by El-Batrawy et al. (2018) who measured mean values of heavy metals $(\mathrm{Cu}, \mathrm{Fe}, \mathrm{Zn}$ and $\mathrm{Pb}$ ) equal to $0.02,0.29,0.015 \mathrm{mg} / \mathrm{l}$ and 5.98 $\mu \mathrm{g} / \mathrm{l}$, respectively in water collected from 6 sites at Lake Burullus and lower Cd $(0.19$ $-0.47 \mu \mathrm{g} / \mathrm{l})$ than that observed by Nafea \& Zyada, (2015) (4.6- $6.0 \mu \mathrm{g} / \mathrm{l})$. 
The presence of pollutants in aquatic environment exerts its effect on the inhabitant animals at a cellular or molecular level which results in significant changes in biochemical responses that offer important biomarkers for monitoring this aquatic environment, (Vutukuru, 2005). Gómez-Milán et al. (2007) cleared that AST and ALT play a significant role in proteins and amino acid metabolism in different body organs and they are considered as two important key enzymes and sensitive markers to evaluate hepatocellular damage and biliary tract diseases; their elevation may be attributed to tissue damage, particularly liver that leading to their extensive liberation to blood (Ibrahim and Mahmoud, 2005, Fagbuaro et al., 2016 and Tunholi et al., 2011). Also, Varley et al. (1980) and Tunholi et al. (2011) found that the increase in ALT, AST and ALP enzymes correlated with alteration in phospholipid metabolism and the high energy demand of the snail and fish under stressful conditions of intoxication. The present studied biochemical responses included the liver enzymes; ALT, AST and ALP that showed significant high levels in fish and snail collected from Bahr-Tera site followed by Shakhloba site. In the same consequence, El-Khayat et al. (2015b) observed significant increase in AST and ALT, and ALP enzymes in Planorbis and Physa snail samples, collected from Lake Manzala. Bislimi et al. (2013) recorded a significant increase of transaminases activity and catalase in the garden snail specimens (Helix pomatia L) which were collected from polluted area compared to control. Mohamed (2011) indicated that there are significant elevations in the level of ALP, after using of pesticides (Profenophos) against B. alexandrina, which can be explained by the destruction of internal snail cells. Meanwhile, in fish, these results agree with Zaghloul et al. (2008), Tayel et al. (2014), El-Khayat et al. (2016) and Ismail et al. (2017) who reported highly significant increase in the activities of AST, ALT and ALP in serum of $O$. niloticus in fish collected from lakes El-Burullus, Manzala and from highly polluted unlined sites at Giza and El-Beharia canals. The same results were reported in case of different fish species exposed to different heavy metals (Elghobashy et al., 2001 and Gad, 2005). Another biochemical response; the total protein and glucose and the total serum proteins were used in the diagnosis of fish disease and considered as important indicators for the effect of pollutants on snail and fish Tayel et al. (2007) and Saravanan et al. (2011). In this study, there were elevations in serum TP and Alb in snails and fish collected from all Lake Burullus sites. This increase may be attributed to the changes in hepatic protein synthesis (Saad et al., 1984) and Mahmoud et al., 2002) or due to the stress of the polluted habitat. The increase in the serum total protein level was also reported by ElNaggar et al. (1998) for O. niloticus collected from a polluted area along the River Nile at the industrial zone of Helwan and by Zaghloul et al. (2000) for Nile tilapia collected from fish ponds irrigated by agricultural drainage water. In addition, increased values of protein and albumin in fish blood was reported by Authman et al. (2013) in Clarias gariepinus collected from El-Rahawy drain and by El-Khayat et al. (2016) in fish samples collected from Lake Manzala. Meanwhile, the elevations of $\mathrm{TP}$ and Alb in snail tissue go in the same direction as those of El-Khayat et al. (2015a) who reported significant increase of total protein level in all samples of snail collected from Lake Manzala, and Grara et al. (2012) who recorded an increase in the total protein concentration in Helix snails dependent in the presence of metal dust. Masaya et al. (2002) highlighted a significant increase in the total protein under the effect of a chemical stress at different biological models. Mello-Silva et al. (2009) observed significant changes in protein metabolism in response to exposure to different concentrations of Euphorbia splendens var. hislopii latex, with significant increases in snails exposed to 0.8 and $1.0 \mathrm{mg} / \mathrm{l}$ of the latex, indicating latex toxicity. Glucose 
has been studied as a sensitive and an indicator of pollutants causing environmental stress in fish caused by physical factors (Manush et al., 2005). Stress factors; such as hunger, hypoxic conditions, and heavy metal toxicity; resulted in changes in carbohydrate metabolism (Kuşatan \& Cicik, 2004 and Tunçsoy et al., 2015). In the present study, glucose levels in B. alexandrina snails collected from different sites at Lake Burullus were highly significantly increased $(\mathrm{P}<0.01)$. This may be due to degradation of glycogen to supply the parasite requirements and hyperglycemia associate with the process of glyconeogenesis. This result agrees with El-Khayat et al. (2016) who reported significant increase of glucose in tissue extract of snails exposed to $\mathrm{Cu}, \mathrm{Pb}$ and $\mathrm{Zn}$ through different experimental designs. While disagrees with Nedjoud Grara et al. (2012) and Bislimi et al. (2013) who found a decrease in the concentration of glucose and lipids in the snails collected from a region Trepça smelter in Mitrovica, Kosovo polluted with heavy metals. On the other hand, the decrease in serum glucose levels of fish samples collected from different Lake Burullus sites may be attributed to the industrial and agriculture effluents (including heavy metals). Other biochemical responses that used as biomarkers in the present study are creatinine and urea. Elghobashy et al. (2001) showed that serum creatinine can be used as a rough index of the glomerular filtration rate as the high concentrations indicate the kidney dysfunction. In the same consequence Bisop et al. (1996) cleared that urea is only synthesized in liver from excess amino acids and excreted by kidney and major illness may increase urea levels. Regarding the serum creatinine in the present study showed no significant increase (16 -95\% of change) in creatinine of fish collected in all sites of Lake Burullus except in Shakhloba that showed significant increase ( $171 \%$ of change) this may be attributed to the action of heavy metals on the glomerular filtration rate which causes pathological changes in the kidney and gill dysfunction (Lockhart and Metner, 1984). The author Chen et al. (2004) concluded that kidney damage may results in reduction in renal blood flow with reduction in glomerular filtration rate, which characterized by the increase in blood creatinine. According to Yousuf et al. (2012) the excretory system in fish is unique and most of the nitrogenous wastes are excreted via the gills with only a small fraction excreted by the kidney. Another explanation of the present findings is that the increase of creatinine level might be induced by glomerular insufficiency, increased muscle tissue catabolism or the impairment of the carbohydrates metabolism (Hadi et al., 2009). Meanwhile, snail collected from most sites showed increase in urea and decrease in creatinine. In accordance with this, the exposure of B. glabrata to Euphorbia splendens var. hislopii latex caused the urea content increased which reflects a disturbance in the snail's regulation of their metabolism due to intoxication caused by the latex exposure. This result agrees with El-Khayat et al. (2015a) who reported significant increase in urea and showed alteration, ranged between insignificant decrease and increase in creatinine of snail samples collected from different sites at Lake Manzala. In present snails samples creatinine showed significant decrease, and urea was ranged between normal to insignificant increase indicating slight affection in liver and/or muscle. The present samples showed increase in creatinine level in all sites and only significance was exhibited in Shakhloba site while urea showed slight alteration with percentage change ranged between -36 to $20 \%$ indicating affected liver.

Histopathological changes were mostly confined to organs directly involved in their metabolism and detoxification and considered as a reflection of the overall health of the entire population in the ecosystem (Mohamed, 2009). Histopathological assessment of fish tissues allows for early warning signs of disease and detection of 
long-term injury in cells, tissues, or organs (Marchand et al., 2009). The use of physiological and biochemical parameters as indicators of histopathological changes have been widely used as biomarkers in the health evaluation of animal organisms (El-Khayat et al., 2015a). The present histopathological observations in head foot region of $B$. alexandrina snails showed shrinkage in the mucous secreting unicellular glands, splitting fiber tissues, increased empty spaces and atrophy. Changes of hepatopancreas included cellular necrosis, atrophy, degeneration, fusion between hepatopancreatic tubules and dilated lumen. The hermaphrodite gland showed vacuolation, atrophy in different stages of sperm, degenerative changes in most ova and disappearance of most component in gonad cells. These results go well with the present high levels of $\mathrm{Pb}$ and $\mathrm{Fe} \mathrm{s}$ in water samples representing the lake. Similar histopathological alterations were observed by El-Khayat et al. (2015 a\&b) who studied the effect of pollution on Lake Manzala ecosystem and referred that snail organs were affected by the high concentration of $\mathrm{Cu}, \mathrm{Cd}, \mathrm{Pb}$ and $\mathrm{Zn}$ recorded in the lake. Also, Stentiford and Feist (2005) illustrated that stress responses in invertebrates can occur following acute or chronic exposures to contaminated environments. Usheva et al. (2006) explained that the molluscan digestive gland have been known as target organs for contaminant effects because it plays a major role in contaminant uptake where intracellular digestion and metabolism of inorganic and organic chemicals takes place. The muscle tissues of the fish come into close contact with pollutants dissolved in water. The present studied fish muscle showed degeneration in muscle bundles accompanied with focal areas of necrosis, atrophy of muscle bundles and splitting of muscle fibers. These results agree with those observed by many investigators who have studied the effects of different pollutants on fish muscles (Mohamed, 2009; Mohamed, 2010; El-Khayat et al., 2016 and Vijayalakshmi and Shehnaz Begum, 2017). The fish gill is a multifunctional organ that involved in respiration and homeostatic activities such as osmoregulation, metabolism, circulation of hormones nitrogen excretion and acid-base balance (Haaparanta, 1997). In the present study, alterations of the gills included degenerative and necrotic changes in the epithelium of gill filaments, fusion, edema, lifting of the lamellar epithelium, dilation and congestion of the blood vessels of gill filaments. These cellular proliferations in respiratory lamellar epithelium may lead to great disturbance of gas exchange and ion regulation for osmoregulation performed by the gills (Yacoub, 2003). These results are similar to those reported in fish samples after subjecting to change of water quality as a results to industrial, agricultural and sewage wastes (Yacoub, 2004, Ibrahim and Tayel 2005, Yacoub et al. 2008, AbdelAziz et al., 2011 El-Khayat et al., 2016 and Mohamed et al., 2017). The present fish liver sections collected from different sites of the examined lake showed vacuolar degeneration of the hepatocytes, focal areas of necrosis, nuclear pyknosis, and haemorrhage. Mela et al. (2007) showed that hepatic necrosis and inflammation are indicative of infection or toxic injury by contaminants while necrosis is resulted from the presence of chemicals within cells that disturb the physiological process such as; inhibition or failure in the synthesis of enzymes, proteins and ATP molecules, impaired carbohydrate metabolism and production of reactive oxidative species as well as damage in the cell membrane. According to Oliva et al. (2013) necrosis found in the fish liver is usually related to contaminants found in water or sediment with $\mathrm{Cd}$ and $\mathrm{Cu}$ concentrations.

The histopathological changes observed in the liver of $O$. niloticus are similar to that recorded by Zaghloul et al. (2007) and Abdel-Aziz et al. (2011), which confirmed the present study biochemical change in the liver enzymes; AST and ALP 
and in agreement with Ajani and Akpoilih (2010) who found that the liver tissue necrosis was associated with the elevation of the activates of ALT and AST. The kidney is a major organ involved in fluid and ionic balance of fish. The present kidney pathological alterations included vacuolization, dilation in renal cells, necrosis, glomerular shrinkage and vacuolar degeneration in the epithelium of renal tubules and separation from the basement membrane resulting from edema. These symptoms are similar with that observed by Zaghloul (2000) and Zaghloul et al. (2007) and similar to those found in Mugil sp. and C. carpio that exposed to lindane (Ortiz et al., 2003); O. mykiss infected with Micrococcus luteus (Aydin et al., 2005) O. niloticus exposed to ammonia (Benli et al., 2008); Dicentrarchus labrax exposed to mercury (Giari et al., 2007) and O. niloticus exposed to $\mathrm{Cu}$ and $\mathrm{Pb}$ (Osman et al., 2009). Iqbal et al. (2004) explained that the kidney is the site of detoxification of all types of toxins such as heavy metals. Also, the kidney is a vital organ of body and proper kidney function is to maintain the homeostasis. Rangsayatorn et al. (2004) explained also, that the appearance of vacuoles and tubular degeneration might be a result of a general metabolic disturbance leading to an intensified reabsorption of amino acids from the ultra-filtrate. So, the obtained results revealed that kidney was found to be affected by changes in water quality at histopathological level while at biochemical level still functioning approximately normal suggesting the importance of histopathology as an early warning biomarker.

\section{CONCLUSION}

There were adverse effects on histological and biochemical parameters of contaminated fish with heavy metals at polluted studied areas in Lake Burullus. The high histological alterations were found in head-foot, hepatopancreas and hermaphrodite glands of snails and in the gills, liver, kidney and muscles of fish. The most affected samples were from Bahr Tera site in El-Hamoul center and Shakhloba site in Sidi-Salem, while samples of Prempal site in Mottobus center were the least. This may be attributed to the wastewater discharged into the lake without any treatment. Histopathological alterations in B. alexandrina snails and Nile Tilapia under the influence of pollutants can be used as a sensitive model to monitor and assess the aquatic pollution in Lake Burullus.

\section{REFERENCES}

Abbas, H. and Ali, F. (2007): Study the effect of hexavalent chromium on some biochemical, cytotoxicological and histopathological aspects of the Oreochromis spp. fish. Pak. J. Biol. Sci., 10: 3973-3982.

Abd El-Aziz, E.A.; El- Habashi, N. and Yones,E.M. (2011): Histopathological alterations of Nile Tilapia (Oreochromis niloticus) induced by environmental contamination in Lake Burullus, Egypt. Egypt. J. Comp. Path \& Clinic Path., 24 (1): 93-117.

Abdel-Moneim, A.M.; Al-Kahtani, M.A. and Elmenshawy, O.M. (2012): Histopathological biomarkers in gills and liver of Oreochromis niloticus from polluted wetland environments, Saudi Arabia. Chemosphere, 88: 1028-1035.

Ajani, E.K. and Akpoilih, B.U.J. (2010): Effect of chronic dietary copper exposure on histology of common carp (Cyprinus carpio). J. appl. Sci. Environ. Manag. 14:39-45. 
Al-Yousuf, M. H.; El-Shahawi, M. S. and Al-Ghais, S. M. (2000): Trace metals in liver, skin and muscle of Lethrimus lentjan fish species in relation to body length and sex. The sci. of the total Enviro., 256: 87 - 94.

APHA (2005): Standard Methods for the Examination of Water and Wastewater, 21st ed. American public Health Association. New York.

Authman, M. M.N.; Seham, A.; Ibrahim, M. A.; El-Kasheif, and Gaber, H. S. (2013): Heavy Metals Pollution and Their Effects on Gills and Liver of the Nile Catfish Inhabiting El-Rahawy Drain, Egypt. Global Veterinaria, 10 (2): 103115 .

Aydin, S.; Ciltes, A.; Yetim, H. and Akyurt, L. (2005): Clinical, pathological and haematological effects of Micrococcus luteus infections in rainbow trout (Oncorhynchus mykiss Walbaum). J. Animal Vet. Adv., 4(2): 167-174.

Bancroft, J.D. and Stevens, A. (1996): Theory and Practice of Histological Techniques" 4th ed. Edinburgh: Churchill Livingstone, p.766.

Batton, C.J. and Crouch, S.R.(1977): Enzymatic colorimetric determination of urea. Anal. Chem., 49: 464-469.

Belfield, A. and Goldberg, D.M. (1971): Revised assay for serum phenyl phosphatase activity using 4-amino-antipyrine. Enzymes 12, 561- 573.

Benli, A.Ç.K.; Köksal, G. \& Özkul, A. (2008): Sublethal ammonia exposure of Nile tilapia (Oreochromis niloticus L.): Effects on gill, liver and kidney histology. Chemosphere, 72 (9): 1355-1358.

Bergmeyer, H.U.; Herder,M. and Rej,R. (1986): Approved recommendation on IFCC method for the measurement of catalytic concentration of enzymes. Part 2.J Clin. Chem. Clin. Biochem.: 24-49.

Bernet, D.; Schmidt, H.; Meier, W.; Burkhardt-Holm, P. and Wahli, T. (1999): Histopathology in fish: Proposal for a protocol to assess aquatic pollution. J. Fish Diseases, 22: 25-34.

Bislimi, K.; Behluli, A.; Halili, J.; Mazreku, I. and Halili, F. (2013): Impact of Pollution from Kosova'S Power Plant in Obiliq on Some Biochemical Parameters of the Local Population of Garden Snail (Helix Pomatia L.) Resources and Environment. 3: 15-19.

Bisop, M.H.; Dubenn-Engelkiry, J.L. and Fody, M.D. (1996): Non protein nitrogen, clinical chemistry, principles, procedures, correlations. East Washington Square, Philadelphia, PA 19106. Chapter 16: 341-356.

Blackmore, G. (2000): Field evidence of metal transfer from invertebrate prey to an intertidal predator, Thais clavigera (gastropoda: muricidae) Estuar. Coast. Shelf Sci. vol. 51, pp. 127-139.

Censi, P., Spoto, S. E., Saiano, F., Sprovieri, M. and Mazzola, S. (2006): Heavy Metals in Coastal Water System: A Cast Study from North Western Gulf of Thailand. Chemosphere, 64:1167-1176.

Chen, C.; Wooster, G.A. and Bowser, P.R. (2004): Comparative blood chemistry and histopathology of tilapia infected with Vibrio vulnificus or Streptococcus iniae or exposed to carbon tetrachloride, gentamicin or copper sulfate. Aquaculture 239, 421-443.

Domas, B. T. (1975): Standards for total serum protein assays. A collaborative study. Clinical Chemistry, 21:1159-66.

Elagba, H.; Ali, M. and Abdel-Rahman, O. (2014): Heavy Metals in Water, Muscles and Gills of Oreochromis niloticus Collected from the Sewage-Treated Water and the White Nile, Sudan. Vol. 4, No.06. 
El-Batrawy, O. A.; El-Gamma, M. I.; Mohamadein, L. I.; Darwish, D. H. and. ElMoselhy, K. M. (2018): Impact assessment of some heavy metals on tilapia fish, Oreochromis niloticus, in Burullus Lake, Egypt. The Journal of Basic and Applied Zoology .79:13.

Elghobashy, H.A.; Zaghloul, K.H. and Metwally, M.A. (2001): Effect of some water pollutants on the Nile tilapia, Oreochromis niloticus collected from the River Nile and some Egyption Lakes. Egypt. J. Aquat. Biol. Fish. 5, 251-279.

El-Khayat, H.M.M.; Gaber, H.S.; Abdel-Hamid, H.A.; Mahmoud, K.M.A. and Abu Taleb, H.M.A. (2016): Snails and Fish as Pollution Biomarkers in Lake Manzala and Laboratory B: Lake Manzala fish. Fish Aquac J 10 (8):451- 463.

El-Khayat, H.M.M.; Abdel-Hamid, H.; Gaber, H.S.; Mahmoud K.M.A. and Flefel, H. (2015 a): Snails and fish as pollution biomarkers in Lake Manzala and laboratory A: Lake Manzala snails. Fish Aquacul. J., Vol, 6, no. 4, 1000153.

El-Khayat, H.M.M.; Mahmoud, K.M.A.; Gaber, H.S.; Abdel-Hamid, H.A.; and Abu Taleb, H.M.A. (2015 b): Studies on the effect of pollution on Lake Manzala ecosystem in Port-Said, Damietta and Dakahlia Governorates, Egypt. J. Egypt. Soc. Parasitol. (JESP), vol. 45 (1): 155-168.

El-Naggar, G. O.; Zaghlol, K. H. ; Salah El-Deen, M.A. and Abo-Hegab, S.(1998): Studies on the effect of industrial water pollution along different sites of the River Nile on some physiological and biochemical parameters of the Nile tilapia, Oreochromis niloticus. 4th Vet.Med.Zag.Congress (26-28 August 1998 in Hurghada): 713-735.

Emara, E. K.M.; Farfour, S.A. and. Mousa, I.E. (2016): Environmental Studies on the Effects of Aquaculture and Drainage Wastewaters on Lake Burullus. AmEuras. J. Agric. \& Environ. Sci., 16 (2): 410-423.

Fagbuaro, O.; Iwalaye. O.A. and Ariyo, A.F.(2016): Heamatological and serum biochemical profile of Nile tilapia, Oreochromis niloticus from Ero Dam in Ikun Ekiti, Ekiti State, Nigeria. Am. J. Res. Commun, 4:200-205.

Gad, N.S. (2005): Impact of environmental pollution in the southern region of Lake Manzalah Egypt on some biochemical parameters of Tilapia Zilii. J. Egypt. German Soc. Zool. 48A, 279-298.

Giari, L.; Manera, M..; Simon, E. and Dezfuli, B. (2007): Cellular alterations in different organs of European Sea bass Dicentrarchus labrax (L.) exposed to cadmium. Chemosphere, 67(6): 1171-1181.

Gohera, M. E.; Abdoa, M. H.; Bayoumy, W.A. and Mansour El-Ashkara, T. Y. (2017): Some heavy metal contents in surface water and sediment as a pollution index of El-Manzala Lake, Egypt. J. Bas. \& Environ. Sci., (2):210225.

Gómez-Milán, E.; Cardenete, G. and Sánchez-Muros, M.J. (2007): Annual variations in the specific activity of fructose 1,6-bisphosphatase, alanine aminotransferase and pyruvate kinase in the Sparus aurata liver. Comp. Biochem. Physiol. 147:49-55.

Grara, N.; Atailia, A.; Boucenna, M.; Khaldi, F. and Berrebbah, H. et al. (2012): Effects of Heavy Metals on the Snails Helix aspersa Bioindicators of the Environment Pollution for Human Health. Int. Conf. Appl. Life Sci. Turkey.

Haaparanta A.; Voltomen, E.T. and Haffman, R.W. (1997): Gill anomalies of perch and roach from lakes differing in water quality. Journal of Fish Biology, 50: 575-591.

Hadi, A.; Shokr, A. and Alwan, S. (2009): Effects of aluminum on the biochemical parameters of fresh water fish Tilapia zillii. J. Sci. Appl. 3:33-41. 
Hamed, A. S.; Alim, D. I.; Babiker, E. M. and Saad, H. A. (2015): Assessment of Heavy Metal pollution in the White Nile River in the Sudan, International Journal of Advance Research Vol. 3(10): 1270-1275.

Haram Hassan Abass Bakhiet, (2015): Determination of Heavy Metals in fish tissues and water from White Nile Khartoum City-Sudan, Journal of Environment Protection and sustainable Development Vol. 1(3): 178-181.

Ibrahim, M.M. (2006): Energy allocation patterns in Biomphalaria alexandrina snails in response to cadmium exposure and Schistosoma mansoni infection. Exp. Parasitol., vol. 112, pp. 31-36.

Ibrahim, S.A. and Mahmoud, S.A. (2005): Effect of heavy metals accumulation on enzyme activity and histology in liver of some Nile fish in Egypt. J. Aquat. Biol. Fish., 9 (1): $203-219$.

Ibrahim, S.A. and Tayel, S.I. (2005): Effect of heavy metals on gills of Tilapia zillii inhabiting the River Nile water (Domietta Branch) and El-Rahawy Drain. Egyptian Journal of Aquatic Biology and Fisheries, 9 (2): 111-129.

Iqbal, F.; Qureshi, I. Z. and Ali, M. (2004): Histopathological changes in the kidney of common carp, Cyprinus carpio following nitrate exposure. Journal of Research Sciences, 15 (4): 411-418.

Ismail, N.M.; Ali, S.E. and Mohamed, I.K. (2017): Biochemical and histological biomarker approaches in the assessment of the water pollution in some lined and unlined watercourses of Egypt. International Journal of Fisheries and Aquatic Studies 2017; 5(3): 288-296.

Jobin, W.R. (1970): Population dynamics of aquatic snails in three farm ponds in Puerto Rico. Amer. J. Trop. Med. Hyg. 19:1038-48.

Kuşatan, Z. and Cicik, B. (2004): Clarias lazera (Valenciennes, 1840)'da kadmiyum'un solungaç, karaciğer, böbrek, dalak ve kas dokularındaki birikimi. SDÜ. Eğirdir Su Ürünleri Fakültesi Dergisi, 2(12): 59-66.

Laszczyca, P.; Augustyniak, M.; Babczynska, A.; Bednarska, K.; Kafel, A.; Migula, P.G. and Wilczek, I.(2004): Witas "Profiles of enzymatic activity in earthworms from zinc, lead and cadmium polluted areas near Olkusz (Poland)": Environ. Int., vol. 30, p. 901.

Lockhart, W.L. and Metner, D.A.(1984): Fish serum chemistry as a pathology tool. In: Contamin-ant Effects on Fisheries, Cairns VW, Hodson PV, Nriagu JO (Eds.). New York, Wiley Interscience, 73-86.

Mac Farlane, G. R. and Burchette, M. D. (2000): Cellular Distribution of Copper, Lead and Zinc in the Grey Mangrove, Aviciennamarina (Forsk) Vierh, Aquat. Bot.68;45-59.

Mahmoud, M.R. El-Abhar, H.S. and Saleh, S. ( 2002): The effect of Nigeila sativa oil against the liver damage induced by Schistosoma mansoni infection in mice. J. Enthnopharmacol., vol. 79, no. 1, pp. 1-11.

Maltchik, L.; Lanés, L.E.K.; Stenert, C. and Medeiros, E.S.F. (2010): Species-area relationship and environmental predictors of fish communities in coastal freshwater wetlands of southern Brazil. Environ. Biol. Fish. pp: 88: 25-35.

Manush, S.M.; Pal, A.K.; Das, T. and Mukherjee, S.C. (2005): Dietary high protein and vitamin $\mathrm{C}$ mitigate stress due to chelate claw ablation in Macrobrachium rosenbergii males. Comparative Biochemistry and Physiology A, 142(1): 1018.

Marchand, M.J.J.; Van Dyk, C.; Pieterse, G.M.; Barhoorn, I.E.J. and Borman, M.S. (2009): Histopathological alterations in the liver of the sharptooth catfish 
Clarias gariepinus from polluted aquatic ecosystems in South Africa. Environmental Toxicology, 24(2): 133-147.

Masaya, M.; Yoshinobu, H.; Ai, Y.; Maki, K. and Yasuo, O. (2002): Determination of cellular levels of nonproteinthiols in phytoplankton and their correlation with susceptibility to mercury. J. Phycol., 38: 983.

Mela, M.; Randi, M.A.F.; Ventura, D.F.; Carvalho, C.E.V.; Pelletier, E. \& Oliveira Ribeiro C.A. (2007): Effects of dietary methylmercury on liver and kidney histology in the neotropical fish Hoplias malabaricus. Ecotoxicol. Environ. Saf., 68 (3): 426-435.

Mello-Silva, C.C.; Pinheiro, J.; Vasconcellos, M.C. and Rodrigues, M.L.A. (2006): Physiological changes in Biomphalaria glabrata Say, 1818 (Pulmonata: Planorbidae) due to the concentration of the latex of Euphorbia splendens var.hislopii (Euphorbiaceae). Mem. Inst. Oswaldo Cruz., 101: 03-08.

Mohamed, F.A.S. (2009): Histopathological studies on Tilapia zilli and Solea vulgaris from lake Quran, Egypt. World J. Fish Marine Sci.1:29-39.

Mohamed, F.A.S. (2010): Histopathological changes in Oreochromis niloticus, Tilapia zillii, Oreochromis aureus and Synodontis schall inhabiting Ismailia Canal. J. Egypt. Acad. Soc. Environ. Develop. 11 (1): 9-31.

Mohamed, I.K.; Ali, S.E and Ismail, N.M. (2017): Impact of watercourse lining in Egypt on the gills of the Nile tilapia Oreochromis niloticus: Histopathological and biochemical study. International Journal of Fisheries and Aquatic Studies, 5(3): 88-94.

Mohamed, R. (2011): Impact profenophos (pesticide) on infectivity of Biomphalaria alexandrina snails with schistosoma mansoni miracidia and on their physiological parameters. Open J Ecol. 1: 41-47.

Moolman, L.; Van Vuren, J.H.J. and Wepener, V. (2007): Comparative studies on the uptake and effects of cadmium and zinc on the cellular energy allocation of two freshwater gastropods": Ecotoxicol. Environ. Saf., vol. 68, pp. 443-450.

Moustafa, M.M.; Ali, M.H.H.; Abdel-Satar, A.M.; Mohamed, T.Y. and Madbouly, S.M. (2010): Water quality assessment of Rosetta and Damietta branchs, River Nile, Egypt. African J. Biol. Sci., 6(2): 127-142.

Nafea, E.M.A. and Zyada, M.A. (2015): Biomonitoring of heavy metals pollution in Lake Burrullas, Northern Delta, Egypt. African Journal of Environmental Science and Technology, 9(1): 1-7.

Nedjoud G.; Amira A.; Mounir B.; Fadila Kh.; Houria B. and Mohamed R. D. (2012): Effects of Heavy Metals on the Snails Helix aspersa Bioindicators of the Environment Pollution for Human Health International Conference on Applied Life Sciences (ICALS) Turkey, September 10-12.

Oliva, M.; Vicente-Martorell, J.J.; Galindo-Riå, M.D. and Perales, J.A. (2013): Histopathological alterations in Senegal sole, Solea senegalensis, from a polluted Huelva estuary (SW, Spain). Perales Fish Physiol Biochem 39: 523545.

Oliveira Ribeiro, C.; Nathalie, M.; Gonzalez, P.; Yannick, D.; Jean-Paul, B.; Boudou, A. and Massabuau, J. (2008). Effects of dietary methylmercury on zebrafish skeletal muscle fibers. Environ. Toxicol. Pharmacol., 25: 304-309.

Ortiz, J.; Gonzalez de Canales, M. and Sarasquete, C. (2003): Histopathological changes induced by lindane $(\gamma-\mathrm{HCH})$ in various organs of fishes. Sci. Mar., 67(1): 53-61. 
Osman, M.; El-Fiky, S.; Scheir, Y. and Abeer, A. (2009): Impact of water pollution on histopathological and electrophoretic characters of Oreochromis niloticus fish. Res. J. Environ. Toxicol., 3(1): 9-23.

Ozturk, M.; Ozozen, G.; Minareci, O. and Minareci, E. (2009): Determination of Heavy Metals in Fish, Water and Sediments of Avsar Dam Lakein Turkey. Iran. J. Environ. Health. Sci. Eng., Vol. 6, No. 2, pp. 73-80.

Peebuaa P.; Kruatrachuea M.; Pokethitiyooka P. \& Kosiyachindaa P. (2006). Histological Effects of Contaminated Sediments in Mae Klong River Tributaries, Thailand, on Nile tilapia, Oreochromis niloticus. Science Asia, 32, 143-150.

Rangsayatorn, N.; Kruatrachue, M.; Pokethitiyook, P.; Upatham, E.S.; Lanza, G.R. and Singhakaew, S. (2004): Ultrastructural changes in various organs of the fish Puntius gonionotus fed cadmium-enriched cyanobacteria. Environ Toxicol 19:585-593.

Reitman, S. and Frankel, S. (1957): A colorimetric method for the determination of serum glutamic oxalacetic and glutamic pyruvic transaminases. Am. J. Clin. Pathol., 28: 56-63.

Romeis, B. (1989): Mikroskopische Technik. Auflage, Urban \& Schwarzenb- erg, Munchen-Wien- Baltimore., 17: 235-236

Saad, A.M.; Hussein, M.F.; Bushara, H.O.; Dargie J.D. and Taylor, M.G. (1984): Erythrokinetics and albumin metabolism in primary experimental Schistosoma bovis infections in Zebu calves. J. Comp. Pathol. 94: 249-262.

Saad, S.M.; El-Deeb, A.E.; Tayel, S.I. and Ahmed, N.A.M. (2011): Haematological and histopatholog-ical studies on Clarias gariepinus in relation to water quality along Rosetta branch, River Nile, Egypt, J. Exp. Biol. Zool. 2011; 7:223-233.

Saeed, S.M and Shaker, I. M. (2008): Assessment of heavy metals pollution in water and sediments and their effect on Oreochromis niloticus in the Northern delta Lakes, Egypt. $8^{\text {th }}$ International Symposium on Tilapia in Aquaculture, Cairo, 12-14 October, 475-490.

Saravanan, M.; Kumar, K. P.; and Ramesh, M. (2011): Haematological and biochemical responses of freshwater teleost fish Cyprinus carpio (Actinopterygii: Cypriniformes) during acute and chronic sublethal exposure to lindane. Pesticide Biochemistry and Physiology, 100(3): 206-211.

Smith, C. G.; Lewis, W. M. and Kaplan, H. M. (2011): A Comparative Morphologic and Physiologic Study of Fish Blood. Prog. Fish Cult., 14:169-172, published 1952, A viable Online, 2011, from, https://doi.org/10.1577/1548-8640(1952)14[169:ACMAPS]2.0.CO;2.

Stentiford, G.D. and Feist, S.W. (2005): A histopathological survey of shore crab (Carcinusmaenas) and brown shrimp (Crangoncrangon) from six estuaries in the United Kingdom": J Invert Pathol., Vol. 88: 136-46.

Syasina, I.; Arbuzova, L.; Zhad'ko, E. and Sokolovskii, A. (2000): Histopathological alterations in organs of the plaice Pleuronectes obscurus from a polluted part of Peter the Great Bay, Sea of Japan. Russian J. Mar. Biol., 26(4): 276-282.

Tayel, S. I.; Ahmed, N. A. M. and EL-Hossiny, M. A.(2014): Impact of diffused pollution on histological and hematological properties of Mugil cephalus and Mugil capito collected from lake Manzalah, Egypt. (IJESE) Vol. 5: 51- 67.

Tayel, S.I.; Ibrahim, S.A.; Authman, M.M.N. and El-Kashef, M.A. (2007): Assessment of Sable drainage canal water quality and its effect on blood and spleen histology of O. niloticus. Afr. J. Biol. Sci., 2: 97-107. 
Tayel, S.I.; Yacoub, A.M. and Mahmoud, S.A. (2008): Histopathological and haematological responses to freshwater pollution in the Nile catfish Clarias gariepinus. J. Egypt. Acad. Soc. Environ. Develop. 9 (4): 43- 60.

Trinder, P. (1969): Detennination of glucose in blood using glucose oxidase with an alternative oxygen acceptor. Ann. Clin. Biochem., 6: 24-27.

Tunçsoy, M.; Duran, S.; Ay, Ö.; Cicik, B. and Erdem, C. (2015): Effects of copper and lead applied singly and in mixture with chitosan on some sera parameters of Clarias gariepinus. Fresen. Environ. Bull. 24(9A): 3029-3034.

Tunholi, V.; Lustrino, D.; Tunholi-Alves, V.; Mello-Silva, C.C. and Maldonado, A. et al. (2011): Biochemical profile of Biomphalaria glabrata (Mollusca: Gastropoda) after infection by Echinostoma paraensei (Trematoda: Echinostomatidae) Parasitol Res, 109: 885-891

U.S.E.P.A. (United States Environmental Protection Agency) (2009): National Recommended Water Quality Criteria. Office of Water, Office of Science and Technology 4304T, pp: 21.

Usheva, L.N.; Vaschenko, M.A. and Durkina, V.B. (2006): Histopathology of the digestive gland of the bivalve mollusk Crenomytilus grayanus (Dunker, 1853) from southwestern Peter the Great Bay, Sea of Japan. Russ J Mar Biol. 32: 166-172.

Varley, H.; Gowenlock, A.H. and Bell, M. (1980): Enzymes. "Practical Clinical Biochemistry". William Heinemann Medical Books, LTD London. 22: 685770.

Vijayalakshmi, M. and Shehnaz Begum, T. (2017): Effect of untreated effluent on histopathological constituents of fresh water fish, tilapia oreochromis mossambicus. Int. J. Pharm Bio. Sci; 8(2): (B) 250-257.

Vutukuru, S. (2005): Acute effects of Hexavalent chromium on survival, oxygen consumption, Hematological parameters and some biochemical profiles of the Indian Major Carp, Labeo rohita', International Journal of Environmental Research and Public Health, vol., 2(3): 456-62.

Yacoub, A.M. (2003): Study of histopathological changes in the gills of Oreochromis niloticus from Lake Manzala due to water pollution. Egyptian Journal of Aquatic Biology and Fisheries, 7(2): 71-86.

Yacoub, A.M. (2004): Histopathological effects of accumulated heavy metals and macronutrients on the gills of some fish species from Bardawil Lagoon.Journal of Egyptian Academic Society of Environmental Development, (D-Environmental studies), 5(1): 111-143.

Yacoub, A.M.; Mahmoud, S.A. and Tayel, S.I. (2008): Health status of Oreochromis niloticus in fish farmirrigate with drainage water in El-Fayoum province,Egypt. Egyptian Journal of Aquatic Research, 34(1): 161-175.

Young D. S.; D.S.; Pestang,L.C. and Giberman,U.(1975): Quantitative determination of creatinine in serum ,plasma and urine .Clin. Chem.,21:( 286).

Yousif, F.; Khalil, M. El-Emam, M. (1992): Evaluation of three common tools in estimating Biomphalaria alexandrina population in irrigation ditches. Egypt. J. Bilh. 14:151-8.

Yousuf, R.; Mir, S.H.; Tanveer, S.; Chishti, M.Z.; Darzi, M.M. and Mir, M.S.(2012): Comparative Bio-chemical Evaluation of Schizothorax niger and Cyprinus carpio from River Jhelum of Kashmir Valley. Res. J. Pharm. Biol. Chem. Sci. 3:116-131. 
Zaghloul, K. H.; Hasheesh, W. S.; Zahran, I.A. and Marie, M.S. (2007): Ecological and biological studies on the Nile tilapia Oreochromis niloticus along different sites of lake Burullus. Egypt. J. Aquat. Biol. \& Fish., 11(3): 57 - 88.

Zaghloul, K.H.; Hassan,E.M. and Abdel Kader,M.H. (2008): Hematoporphyrin Toxicity in the Cultured Oreochromis niloticus. Egypt. J. Exp. Biol. (Zool.), 4: $81-88$.

Zaghloul, K.H.; Omar, W. A.; Azer, W. Z. and Abo-Hegab, S. (2000): Ecological and Biochemical studies on the Nile fish; Oreochromis niloticus cultured in different aquatic habitats. Egypt. J. Zool., 34: 379 - 409.

Zerabruk, T.; Younis M. H.; Younis, S. and Elsanousi, S. (2016): Assessment of heavy metal status of sediment and water in Mainefhi and Toker drinkingwater reservoirs of Asmara City, Eriterea. Amer. J. of Res. Commu., vol, 4(6).

\section{ARABIC SUMMARY}

تأثير بعض المعادن الثقيلة؛ نسيجيا وبيوكيميائيا، على أسماك البلطي النيلى (Breochromis niloticus) وقواقع (Biomphalaria alexandrina) في بحيرة البرلس، مصر.

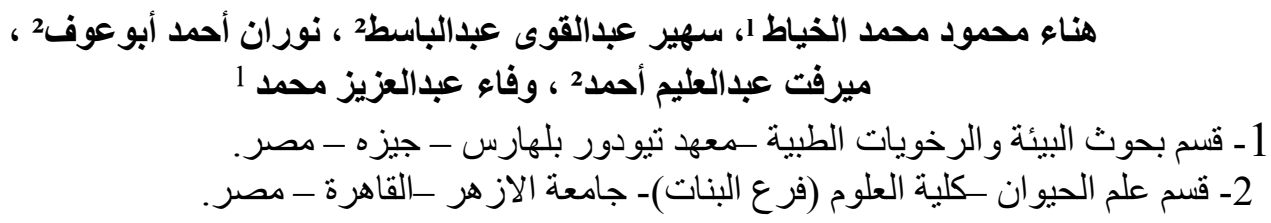

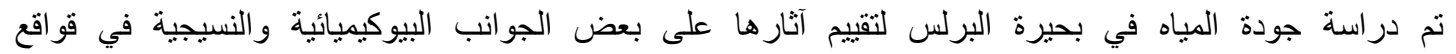
Biomphalaria alexandrina

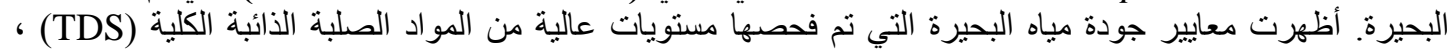

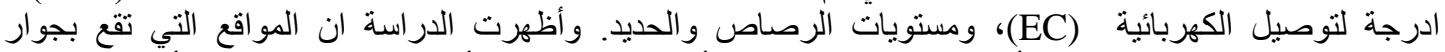

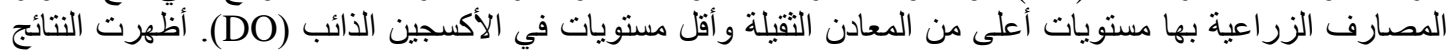

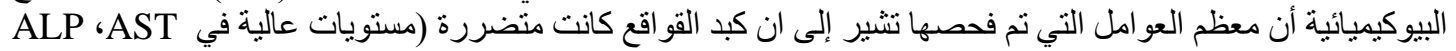

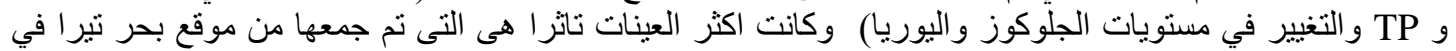

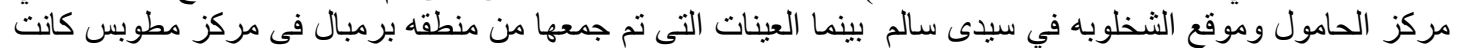

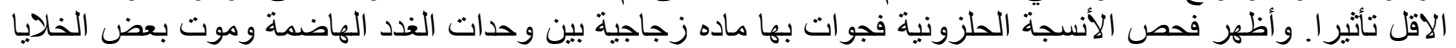

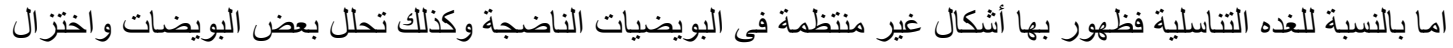

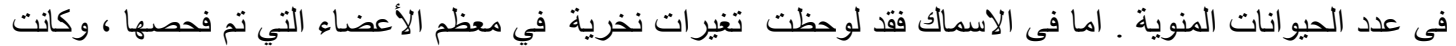

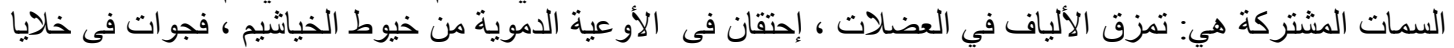

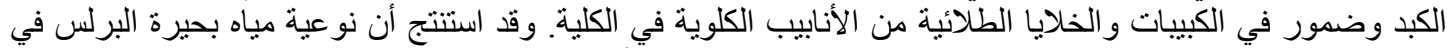

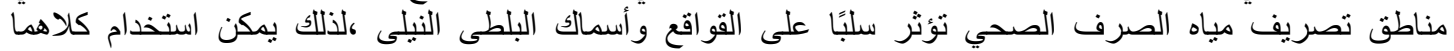
كمؤشر ات حيوية لوجود الملوثات في النظم المائية. 